\title{
Direct Amidation of Aldoses and Decarboxylative Amidation of $\alpha$-Keto Acids: An Efficient Conjugation Method for Unprotected Carbohydrate Molecules
}

\author{
Chia-Ching Cho, ${ }^{\dagger}$ Jia-Nan Liu, ${ }^{\dagger}$ Chung-Hsun Chien,${ }^{\dagger}$ Jiun-Jie Shie, ${ }^{\ddagger}$ Ying-Chu Chen $^{\dagger}{ }^{\dagger}$ and \\ Jim-Min Fang $*,+$, \\ Department of Chemistry, National Taiwan University, Taipei 106, Taiwan, and The Genomics Research \\ Center, Academia Sinica, Taipei, 11529, Taiwan \\ jmfang@ntu.edu.tw
}

Received October 21, 2008

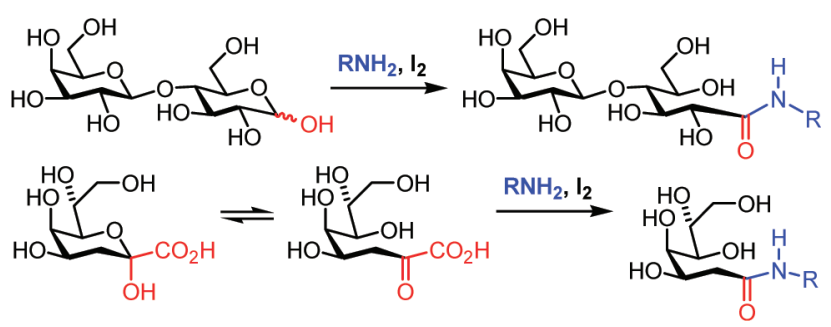

With use of iodine as an appropriate oxidant, unprotected and unmodified aldoses undergo oxidative amidation with a variety of functionalized amines, $\alpha$-amino esters, and peptides, whereas KDO, sialic acid, and other $\alpha$-keto acids proceed with oxidative decarboxylation followed by in situ amidation. Glycoside bond and many other functional groups are inert under such mild reaction conditions. This reaction protocol for direct ligation of carbohydrate molecules looks promising in the development of a general and efficient synthesis of glycoconjugates.

\section{Introduction}

Amides are an important functional group widely found in natural products, pharmaceuticals, and polymers. Besides the conventional methods of amide formation by the coupling reactions between carboxylic acids and amines, ${ }^{1}$ direct methods for oxidative amidation of aldehydes ${ }^{2}$ have been explored. Direct amidation of aldehydes have been achieved by using Nickel peroxide $^{3}$ and transition metal catalysts, e.g., $\mathrm{Pd}(\mathrm{OAc})_{2},{ }^{4} \mathrm{CuI},{ }^{5}$ $\mathrm{RuH}_{2}\left(\mathrm{PPh}_{3}\right)_{4},{ }^{6}\left[\mathrm{Rh}(\mathrm{COD})_{2}\right] \mathrm{BF}_{4},{ }^{7}$ and $\left[\mathrm{Cp} * \mathrm{RhCl}_{2}\right]_{2},{ }^{6,8}$ in combination with oxidants. Aliphatic alcohols also undergo direct amidation with primary amines by catalysis of a ruthenium

\footnotetext{
National Taiwan University.

* Academia Sinica.

(1) Smith, M. B. Compendium of Organic Synthetic Methods; Wiley: New York, 2001; Vol. 9, pp 100-116.

(2) Togo, H.; Iida, S. Synlett 2006, 14, 2159-2175. Ekoue-Kovi, K.; Wolf, C. Chem. Eur. J. 2008, 14, 6302-6315.

(3) Nakagawa, K.; Onoue, H.; Minami, K. J. Chem. Soc., Chem. Commun. 1966, 17-18.

(4) Tamaru, Y.; Yamada, Y.; Yoshida, Z. Synthesis 1983, 474-476.

(5) Yoo, W.-J.; Li, C.-J. J. Am. Chem. Soc. 2006, 128, 13064-13065.

(6) Naota, T.; Murahashi, S.-I. Synlett 1991, 693-694.

(7) Tillack, A.; Rudloff, I.; Beller, M. Eur. J. Org. Chem. 2001, 523-528.

(8) Fujita, K.-i.; Takahashi, Y.; Owaki, M.; Yamamoto, K.; Yamaguchi, R. Org. Lett. 2004, 6, 2785-2788.
}

complex. ${ }^{9}$ In another approach, the oxidants of $t$-BuOOH ${ }^{10,11}$ and Oxone (potassium peroxymonosulfate) ${ }^{12}$ have been utilized in the metal-free amidation of aldehydes and alcohols. Though most aromatic aldehydes are effectively converted to aromatic amides with the above-mentioned methods, ${ }^{3-12}$ direct amidation of aliphatic aldehydes may be problematic due to enolization and other side reactions.

En route to study the scope and limitation of aldehyde substrates in direct amidation, we have previously found that aldoses are successfully converted to aldonamides in ammonia-water using iodine as the oxidant. ${ }^{13}$ Compain and co-workers have also reported that iodine is an appropriate oxidant for direct amidation of protected aldoses, e.g. 2,3,4,6-tetra- $O$-benzylglucopyranose, with functionalized amines, e.g., ethanolamine, in the presence of $\mathrm{K}_{2} \mathrm{CO}_{3}{ }^{14}$ The free hydroxyl group at the C-5

(9) Gunanathan, C.; Ben-David, Y.; Milstein, D. Science 2007, 317, 790792.

(10) Ekoue-Kovi, K.; Wolf, C. Org. Lett. 2007, 9, 3429-3432.

(11) Reddy, K. R.; Maheswari, C. U.; Venkateshwar, M.; Kantam, M. L. Eur. J. Org. Chem. 2008, 3619-3622.

(12) Gao, J.; Wang, G.-W. J. Org. Chem. 2008, 73, 2955-2958.

(13) Chen, M.-Y.; Hsu, J.-L.; Shie, J.-J.; Fang, J.-M. J. Chin. Chem. Soc. 2003, 50, 129-133.

(14) Colombeau, L.; Traoré, T.; Compain, P.; Martin, O. R. J. Org. Chem. 2008, 73, 8647-8650. 
position of the aldose substrate is essential for the oxidative amidation reaction, supporting that only aldose in the hemiacetal form can give the aldonamide product. ${ }^{13,14}$ However, they were unable to convert unprotected aldoses to the desired aldonamide products according to their reaction protocol, i.e., premixing the aldose and amine substrates for $1 \mathrm{~h}$ in tert-butyl alcohol followed by addition of $\mathrm{I}_{2} / \mathrm{K}_{2} \mathrm{CO}_{3}$ and reflux at $90{ }^{\circ} \mathrm{C}$.

We report herein the use of iodine to promote the direct amidation reaction of unprotected and unmodified carbohydrate molecules with a variety of primary amines, including bifunctional amines and peptides. Glycoconjugation with amide linkage has been reported, ${ }^{15,16}$ in addition to other methods ${ }^{17}$ using reductive amination, oxime linkage, and thiazolidine formation. It is noted that immobilization of carbohydrate molecules renders wide applications in glycochemistry and glycobiology, ${ }^{15-17}$ even though the cyclic structure of hemiacetal at the reducing end of saccharides is opened.

Conventional methods for the synthesis of glycoconjugates via amide bond formation usually require prior isolation of aldonic acids or aldonolactones. ${ }^{15,16}$ Lönngren and co-workers have reported the coupling reaction of aldonic acids with proteinaceous amines by using an activating agent. ${ }^{15}$ They have also shown that the neoglycoproteins prepared from di- and trisaccharide acids still hold reasonable binding affinity toward lectins. ${ }^{15}$ In comparison, our method is simple and attractive because linkage of aldoses with amines is irreversibly driven by oxidation with iodine to form a robust amide bond in a onepot operation. An aldose that exists in the cyclic hemiacetal form can be oxidized by iodine in the basic conditions to give an intermediate aldonolactone, ${ }^{13,14}$ which reacts in situ with amine to give the aldonamide product.

\section{Results and Discussion}

To establish the protocol for direct amidation, we first investigated the iodine-promoted reactions of D-glucose with aliphatic primary amines (Table 1). A methanolic solution of D-glucose was stirred with ethylamine hydrochloride salt (1 equiv) and $\mathrm{I}_{2}$ (1.2 equiv) in the presence of $\mathrm{K}_{2} \mathrm{CO}_{3}$ at room temperature for $6 \mathrm{~h}$ to give a quantitative yield of $N$-ethyl gluconamide (1a). Alternatively, a direct amidation of D-glucose was furnished by using aqueous ethylamine $(1 \mathrm{~mL}$ of $70 \mathrm{wt} \%$ solution) and iodine. Excess amine was applied to neutralize the released HI molecules. The hydroxyl groups in saccharides were inert in this amidation reaction, though primary alcohol can be oxidized by $\mathrm{I}_{2} / \mathrm{K}_{2} \mathrm{CO}_{3}$ at elevated temperature $\left(60^{\circ} \mathrm{C}\right) .{ }^{18}$

(15) Lönngren, J.; Goldstein, I. J.; Niederhuber, J. E. Arch. Biochem. Biophys. 1976, 175, 661-669.

(16) (a) Fujimoto, K.; Miyata, T.; Aoyama, Y. J. Am. Chem. Soc. 2000, 122, 3558-3559. (b) Narain, R.; Armes, S. P. Macromolecules 2003, 36, 4675-4678. (c) Hayashida, O.; Hamachi, I. J. Org. Chem. 2004, 69, 3509-3516. (d) Yang, B. Y.; Montgomery, R. Carbohyd. Res. 2005, 340, 2698-2705. (e) Kida, T.; Tanaka, T.; Nakatsuji, Y.; Akashi, M. Chem. Lett. 2006, 35, 112-113. (f) El Ashry, E. S. H.; Awad, L. F.; Hamid, H. A.; Atta, A. I. J. Carbohydr. Chem. 2007, 26, 329-338. (g) Morimoto, N.; Ogino, N.; Narita, T.; Kitamura, S.; Akiyoshi, K. J. Am. Chem. Soc. 2007, 129, 458-459. (h) Kim, K.; Matsuura, K.; Kimizuka, N. Bioorg. Med. Chem. 2007, 15, 4311-4317.

(17) (a) Davis, B. G. Chem. Rev. 2002, 102, 579-601. (b) Gray, G. R. Arch. Biochem. Biophys. 1974, 163, 426-428. (c) Halkes, K. M.; Souza, A. C. de; Maljaars, C. E. P.; Gerwig, G. J.; Kamerling, J. P. Eur. J. Org. Chem. 2005 3650-3659. (d) Nishimura, S.-I.; Niikura, K.; Kurogochi, M.; Matsushita, T.; Fumoto, M.; Hinou, H.; Kamitani, R.; Nakagawa, H.; Deguchi, K.; Miura, N.; Monde, K.; Kondo, H. Angew. Chem., Int. Ed. 2005, 44, 91-96. (e) Lohse, A.; Martins, R.; Jorgensen, M. R.; Hindsgaul, O. Angew. Chem., Int. Ed. 2006, 45, 4167-4172. (f) Larsen, K.; Thygesen, M. B.; Guillaumie, F.; Willatsc, W. G. T.; Jensen, K. J. Carbohyd. Res. 2006, 341, 1209-1234.

(18) (a) Moria, N.; Togo, H. Tetrahedron 2005, 61, 5915-5925. (b) Shie, J.-J.; Fang, J.-M. J. Org. Chem. 2007, 72, 3141-3144.
TABLE 1. Iodine-Promoted Oxidative Amidation of Aldoses with Primary Amines ${ }^{a}$

\begin{tabular}{|c|c|c|c|c|}
\hline entry & aldoses & amines & products & yield, ${ }^{b} \%$ \\
\hline 1 & D-glucose & ethylamine & $1 \mathbf{a}$ & 98 \\
\hline 2 & D-glucose & ethylamine & $\mathbf{1 a A c} \mathbf{c}^{c}$ & 85 \\
\hline 3 & D-glucose & hexylamine & $\mathbf{1 b} \mathbf{A} \mathbf{c}^{c}$ & 80 \\
\hline 4 & D-glucose & cetylamine & $\mathbf{1 c A} \mathbf{c}^{c}$ & 92 \\
\hline 5 & D-glucose & benzylamine & $\mathbf{1 d A \mathbf { A c } ^ { c }}$ & 84 \\
\hline 6 & D-glucose & allylamine & $\mathbf{1 e A c ^ { c }}$ & 85 \\
\hline 7 & D-glucose & ethanolamine & 1fA $\mathbf{c}^{c}$ & 77 \\
\hline 8 & D-glucose & 1,6-diaminohexane & 1gAc $\mathbf{c}^{c}$ & 98 \\
\hline 9 & D-arabinose & benzylamine & $\mathbf{2 d A} \mathbf{A c}^{c}$ & 74 \\
\hline 10 & D-xylose & ethylamine & $\mathbf{3 a A c} \mathbf{c}^{c}$ & 85 \\
\hline 11 & D-galactose & ethylamine & $\mathbf{4 a A} \mathbf{c}^{c}$ & 86 \\
\hline 12 & D-mannose & hexylamine & $\mathbf{5 b A c ^ { c }}$ & 75 \\
\hline 13 & D-GlcNAc & hexylamine & 6bAc $c^{c}$ & 80 \\
\hline 14 & D-GlcA & hexylamine & $7 b$ & 61 \\
\hline 15 & D-cellobiose & ethylamine & $\mathbf{8 a A c} \mathbf{c}^{c}$ & 94 \\
\hline 16 & D-lactose & ethylamine & 9aAc $\mathbf{c}^{c}$ & 95 \\
\hline 17 & D-lactose & cetylamine & $9 \mathbf{c A c} \mathbf{c}^{c}$ & 92 \\
\hline 18 & D-maltose & ethylamine & $10 \mathbf{a A} \mathbf{c}^{c}$ & 93 \\
\hline 19 & D-maltose & cetylamine & $10 \mathbf{c} \mathbf{A} \mathbf{c}^{c}$ & 93 \\
\hline 20 & D-maltotriose & ethylamine & $11 \mathbf{a A} \mathbf{c}^{c}$ & 93 \\
\hline 21 & D-maltotriose & cetylamine & $11 \mathbf{c} \mathbf{A} \mathbf{c}^{c}$ & 91 \\
\hline
\end{tabular}

${ }^{a}$ Aldose $(1 \mathrm{mmol})$ was stirred with iodine $(2 \mathrm{mmol})$ and amine $(4$ $\mathrm{mmol}$ ) in aqueous or methanolic solution at room temperature for 6-13 h. A smaller amount of amine $(1 \mathrm{mmol})$ was used when the reaction was performed in the presence of $\mathrm{K}_{2} \mathrm{CO}_{3}(2 \mathrm{mmol}) .{ }^{b}$ The isolated yield is based on aldose. ${ }^{c}$ The peracetate derivative of aldonamide.

TABLE 2. Iodine-Promoted Oxidative Amidation of Aldoses with Amino Esters and Peptides ${ }^{a}$

\begin{tabular}{|c|c|c|c|c|}
\hline entry & aldoses & amines & products & yield, ${ }^{b} \%$ \\
\hline 1 & D-glucose & gly(OMe) & 12 & 96 \\
\hline 2 & D-glucose & gly(OMe) & $12 \mathbf{A c} \mathbf{c}^{c}$ & 94 \\
\hline 3 & D-glucose & L-val(OMe) & $13 \mathbf{A} \mathbf{c}^{c}$ & 70 \\
\hline 4 & D-glucose & L-ser(OMe) & $14 \mathbf{A} \mathbf{c}^{c}$ & 55 \\
\hline 5 & D-glucose & L-tyr(OMe) & $15 \mathbf{A c}^{c, d}$ & 62 \\
\hline 6 & D-glucose & L-met(OMe) & $16 \mathbf{A c} \mathbf{c}^{c, d}$ & 47 \\
\hline 7 & D-glucose & L-cys(OMe) & $17 \mathbf{A} \mathbf{c}^{c, d}$ & 42 \\
\hline 8 & D-glucose & L-his(OMe) & $18 \mathbf{A} \mathbf{c}^{c, d}$ & 54 \\
\hline 9 & D-glucose & L-lys(OMe) & 19Ac $\mathbf{c}^{c}$ & 78 \\
\hline 10 & D-glucose & L-pro(OMe) & $20 \mathbf{A} \mathbf{c}^{c}$ & 40 \\
\hline 11 & D-glucose & gly-gly(OMe) & $21 \mathbf{A} \mathbf{c}^{c}$ & 91 \\
\hline 12 & D-glucose & gly-L-val(OMe) & $22 \mathbf{A c}^{c}$ & 80 \\
\hline 13 & D-glucose & gly-gly-gly(OMe) & $23 \mathbf{A c} \mathbf{c}^{c}$ & 87 \\
\hline 14 & D-arabinose & $\mathrm{gly}(\mathrm{OMe})$ & $24 \mathbf{A c} \mathbf{c}^{c}$ & 90 \\
\hline 15 & D-xylose & gly $(\mathrm{OMe})$ & $25 \mathbf{A} \mathbf{c}^{c}$ & 91 \\
\hline 16 & D-galactose & gly $(\mathrm{OMe})$ & $26 \mathbf{A c}^{c}$ & 84 \\
\hline 17 & D-mannose & gly $(\mathrm{OMe})$ & $27 \mathbf{A} \mathbf{c}^{c}$ & 70 \\
\hline 18 & D-lactose & gly $(\mathrm{OMe})$ & $28 \mathbf{A c}^{c}$ & 74 \\
\hline 19 & D-maltose & gly(OMe) & $29 \mathbf{A c}^{c}$ & 82 \\
\hline 20 & D-maltose & L-lys-D-ala-D-ala & $\mathbf{3 0}^{e}$ & 66 \\
\hline
\end{tabular}

${ }^{a}$ Two-step procedure: A mixture of aldose $(1 \mathrm{mmol})$, iodine (1.2 $\mathrm{mmol}), \mathrm{K}_{2} \mathrm{CO}_{3}(1.5 \mathrm{mmol})$, and molecular sieves in $\mathrm{MeOH}$ solution was stirred at room temperature for $3 \mathrm{~h}$, followed by addition of a methyl ester of $\alpha$-amino acid (or peptide as the hydrochloric salt, $1-2 \mathrm{mmol}$ ) and $\mathrm{K}_{2} \mathrm{CO}_{3}(1.5 \mathrm{mmol})$. The amidation completed in $12-16 \mathrm{~h}$ at $40{ }^{\circ} \mathrm{C}$. ${ }^{b}$ The isolated yield is based on aldose. ${ }^{c}$ The peracetate derivative of aldonamide. ${ }^{d}$ Only $1.0 \mathrm{mmol}$ of iodine was used. ${ }^{e}$ The reaction was performed with maltose $(0.2 \mathrm{mmol}), \mathrm{I}_{2}(0.2 \mathrm{mmol})$, peptide $(0.1 \mathrm{mmol})$, and $\mathrm{K}_{2} \mathrm{CO}_{3}(0.5 \mathrm{mmol})$. The yield of $\mathbf{3 0}$ (as the $\mathrm{CF}_{3} \mathrm{CO}_{2} \mathrm{H}$ salt) is based on peptide.

The gluconamide was then subjected to acetylation to give 1aAc for full characterization (mp, [ $\alpha$ ], IR, HRMS, ${ }^{1} \mathrm{H}$ and $\left.{ }^{13} \mathrm{C} \mathrm{NMR}\right)$. The iodine-promoted amidation of glucose with other aliphatic and bifunctional amines was also carried out smoothly by similar procedures.

It appeared that the $\mathrm{C}=\mathrm{C}$ double bond, phenyl, hydroxyl, and ester groups were inert under the reaction conditions. The double 
amidation with 1,6-hexanediamine yielded a bis-gluconamide (entry 8, Table 1). Furthermore, a series of unmodified monosaccharides were treated with iodine/amines to give the corresponding aldonamides in good yields. The iodine-promoted amidation of glucuronic acid (entry 14, Table 1) occurred selectively at the $\mathrm{C}-1$ aldehyde group without interference with the C-6 carboxylic group, distinguishing itself from the conventional amidation reaction of saccharide acids. ${ }^{17}$ The oxidative amidation of di- and trisaccharides also proceeded smoothly with retention of the glycoside bonds. The result promises an extension of this reaction protocol to polysaccharides. The neoglycolipids (e.g., 9c, 10c, and 11c) prepared as such can be immobilized on a styrene-coated microtiter plate for binding studies. $^{19}$
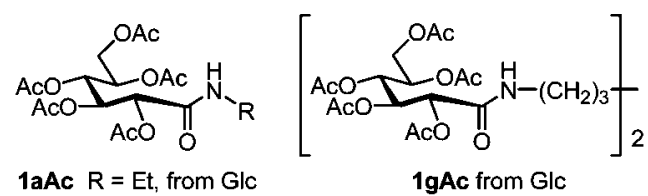

1aAc $R=E t$, from Glc

1bAc $\mathrm{R}=\mathrm{C}_{6} \mathrm{H}_{13}$

1cAc $\mathrm{R}=\mathrm{C}_{16} \mathrm{H}_{33}$

IdAC $\mathrm{R}=\mathrm{CH}_{2} \mathrm{Ph}$

1eAc $\mathrm{R}=\mathrm{CH}_{2} \mathrm{CH}=\mathrm{CH}_{2}$

1fAc $\mathrm{R}=\left(\mathrm{CH}_{2}\right)_{2} \mathrm{OAC}$

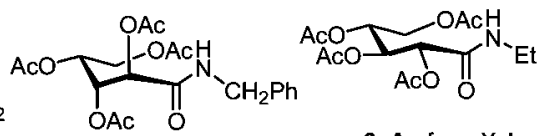

AcO

2dAc from Ara

3aAc from $X y l$
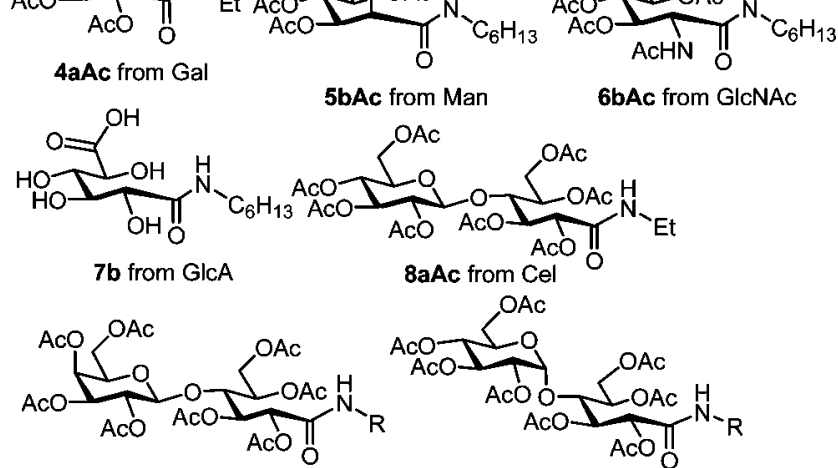

$8 \mathrm{aAc}$ from $\mathrm{Ce}$

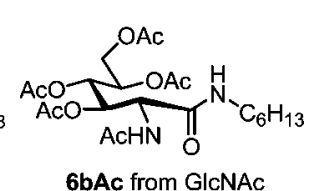

9aAc $R=E t$, from Lac

9cAc $\mathrm{R}=\mathrm{C}_{16} \mathrm{H}_{33}$

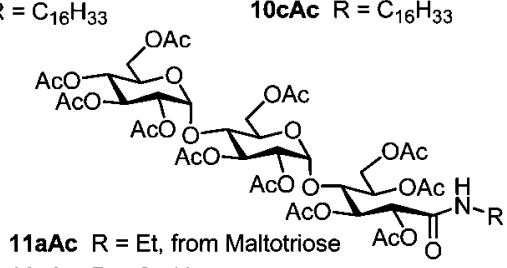

11cAc $\mathrm{R}=\mathrm{C}_{16} \mathrm{H}_{33}$

The amidation of aldoses with less nucleophilic amines, such as $\alpha$-amino esters, was better performed by a one-pot two-step procedure, i.e., an aldose was first oxidized by $\mathrm{I}_{2} / \mathrm{K}_{2} \mathrm{CO}_{3}$, and then $\alpha$-amino ester (as the hydrochloric salt) was added along with $\mathrm{K}_{2} \mathrm{CO}_{3}$ to furnish the amidation. By this means, a high yield of gluconamide $\mathbf{1 2}$ was obtained, and further characterized by its peracetylation derivative 12Ac (Table 2). The yield of gluconamide decreased when aldose and glycine methyl ester were stirred together with $\mathrm{I}_{2} / \mathrm{K}_{2} \mathrm{CO}_{3}$ in methanol, and a side product of methyl gluconate $(\sim 10 \%)$ was also obtained presumably by a competitive methanolysis of the intermediate

(19) Huang, G.-L.; Zhang, H.-C.; Wang, P.-G. Bioorg. Med. Chem. Lett. 2006, 16, 2031-2033. gluconolactone. ${ }^{14,15}$ Similar reactions of D-glucose with other representative $\alpha$-amino esters by the one-pot two-step procedure afforded aldonamides 13Ac-20Ac after subsequent acetylation (entries 3-10, Table 2). No racemerization occurred during the amide formation as evidence of the ${ }^{1} \mathrm{H}$ NMR analyses. The reaction with lysine occurred preferably at the $\varepsilon$-amino group (more nucleophilic than the $\alpha$-amino group) to give 19Ac as indicated by the 2D NMR spectra (COSY, HMQC, and HMBC), which showed correlations of the $\mathrm{C}-1$ amide carbon $\left(\delta_{\mathrm{C}} 166.0\right)$ with $\mathrm{H}-2\left(\delta_{\mathrm{H}} 5.24\right), \mathrm{H}-3\left(\delta_{\mathrm{H}} 5.66\right)$, and the two $\varepsilon$-protons $\left(\delta_{\mathrm{H}}\right.$ $3.23)$. Noteworthily, iodine has been consumed before addition of $\alpha$-amino ester by this one-pot two-step procedure, therefore, conjugation of aldoses with tyrosine, methionine, and histidine was achieved without complication by the side reactions at the phenol, thioether, and imidazole sites. Formation of 20Ac offered an example for the iodine-promoted amidation of aldose with a secondary amine (proline in entry 10, Table 2).

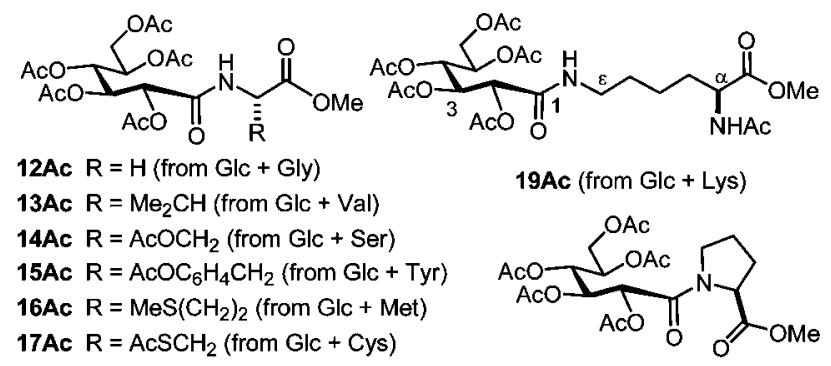

18Ac $\mathrm{R}=\mathrm{ImCH}_{2}$ (from $\mathrm{Glc}+\mathrm{His}$ )

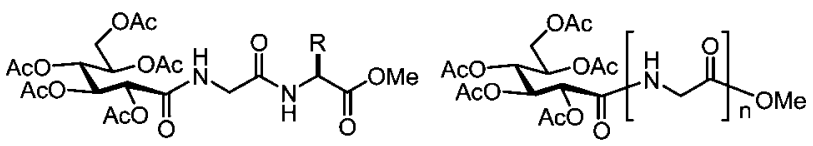

21Ac $R=H$ (from Glc + GlyGly) 22Ac $\mathrm{R}=\mathrm{Me}_{2} \mathrm{CH}$ (from Glc + GlyVal)

23Ac $n=3$ (from Glc + GlyGlyGly)<smiles>COC(=O)CNC(=O)C1[C@H](OC(C)=O)[C@@H](OC(C)=O)[C@H](OC(C)=O)[C@H]1OC(C)=O</smiles>

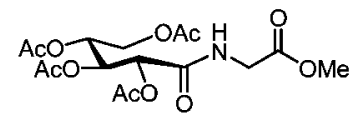

24Ac (from Ara + Gly)

25Ac (from Xyl + Gly)

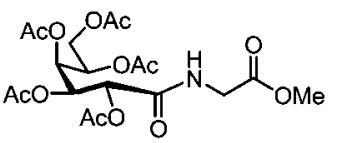

26Ac (from Gal + Gly)

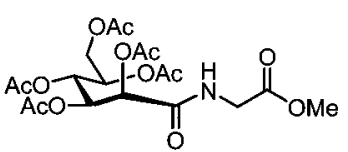

27Ac (from Man + Gly)

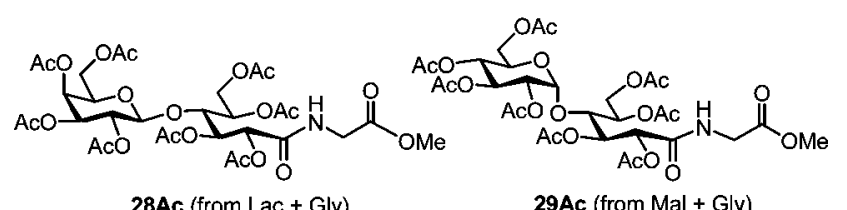

28Ac (from Lac + Gly) 29Ac (from Mal + Gly)

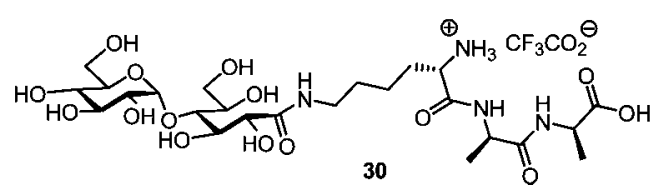

In the reaction with cysteine methyl ester (entry 7, Table 2), the gluconolactone intermediate might first react with the more nucleophilic thiolate group to form a thioester, which was then attacked by the adjacent amino group to give the amide product 17 (Scheme 1). Excess iodine should be avoided; otherwise, a side product of disulfide compound might be obtained by an oxidative coupling of $\mathbf{1 7}$ with cys(OMe). 
SCHEME 1. Iodine-Promoted Oxidative Amidation of Aldoses with L-Cysteine Methyl Ester
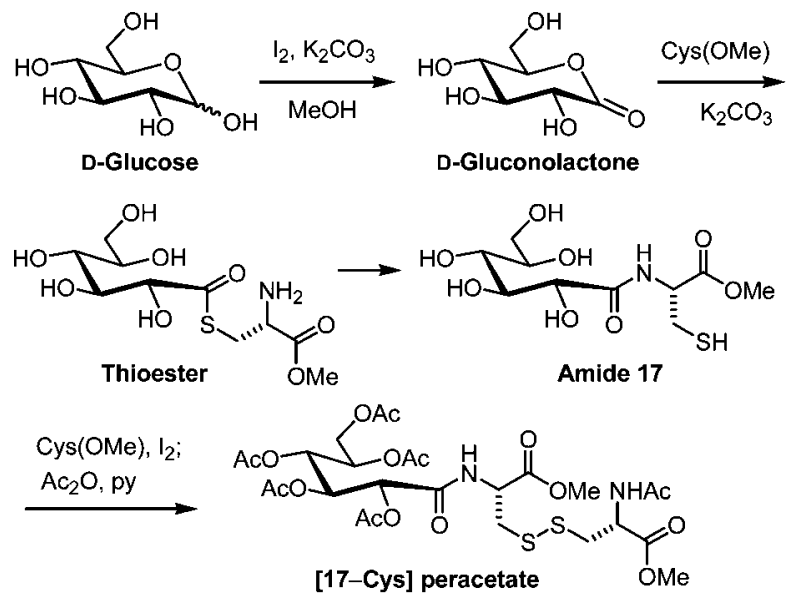

This reaction protocol was also successfully applied to ligation of glucose with di- and tripeptides to give the corresponding peracetates 21Ac, 22Ac, and 23Ac in high yields (entries 11, 12 , and 13 , Table 2). The oxidative amidation reactions of other mono- and disaccharides with glycine methyl ester were similarly carried out (entries 14-19, Table 2). The amidation reaction of maltose with a tripeptide Lys-D-Ala-D-Ala ( 0.1 equiv) afforded the desired product 30 (as the $\mathrm{CF}_{3} \mathrm{CO}_{2} \mathrm{H}$ salt) in $66 \%$ isolated yield. In summary of the results shown in Table 2, glycine and lysine worked well in the oxidative amidation of aldoses with the protocol of one-pot two-step procedure. However, the oxidative amidation with other amino esters was less efficient due to other competitive reactions, in particular, the nucleophilic attack of solvent $(\mathrm{MeOH})$ on the intermediate aldonolactone.

We also utilized the iodine-promoted amidation reaction to link D-lactose with poly-L-lysine and bovine serum albumin. Even though the conjugation efficiency is not optimized in this preliminary study, our reaction protocol looks promising and will be useful for the development of a general one-pot synthesis of carbohydrate-protein conjugates.

The aerobic metabolism of pyruvate to acetyl CoA involves a sequence of decarboxylation, oxidation, and thioester bond formation. By inspiration of this natural course, we explored an iodine-promoted method for decarboxylative amidation of $\alpha$-keto acids in mild reaction conditions. Bode and co-workers have demonstrated the decarboxylative condensation of phenylpyruvic acid and peptide keto acids with $N$-alkylhydroxylamines at $40{ }^{\circ} \mathrm{C}$ to give the amide products. ${ }^{20}$ In our hand, phenylglyoxylic acid reacted with iodine and $\mathrm{RNH}_{2}(\mathrm{R}=\mathrm{Et}$ and $\left.\mathrm{C}_{6} \mathrm{H}_{13}\right)$ at room temperature in aqueous solution to give the corresponding $N$-alkyl benzoates 31a and 31b in $74 \%$ and $91 \%$ yields (Scheme 2). Though the mechanism in the iodinepromoted degradative amidation of $\alpha$-keto acids is not rigorously determined, we speculate that the reaction involves an intermediate of iodinated hemiaminal such as $\mathbf{A}$, by analogy to that described previously. ${ }^{20}$

The iodine-promoted decarboxylative amidation reactions of 2-keto-L-gulonic acid/ethylamine, sialic acid/hexylamine, and KDO/ethylamine were similarly carried out to give L-xylonamide peracetate 32Ac, octanamide 33Ac, and heptanamide 34Ac

(20) Bode, J. W.; Fox, R. M.; Baucom, K. D. Angew. Chem., Int. Ed. 2006, $45,1248-1252$.
SCHEME 2. Iodine-Promoted Decarboxylative Amidation of $\alpha$-Keto Acids

(1)
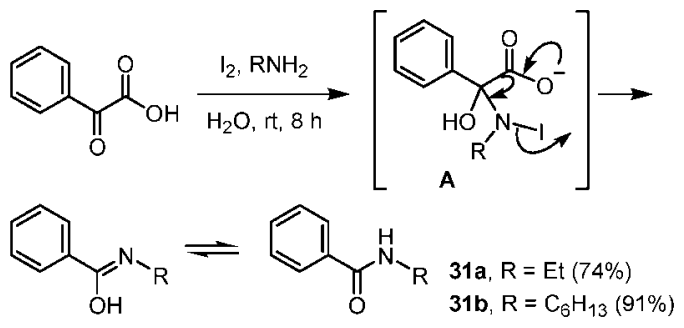

(2)

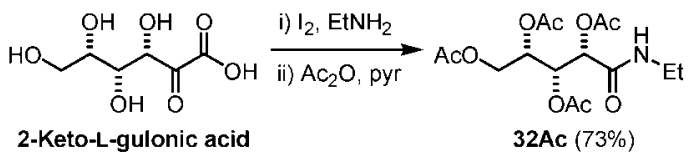

(3)

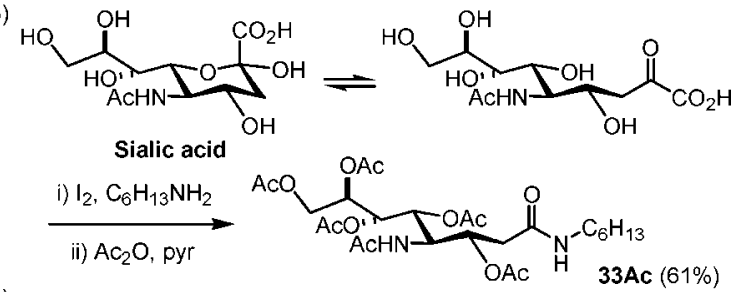

(4)

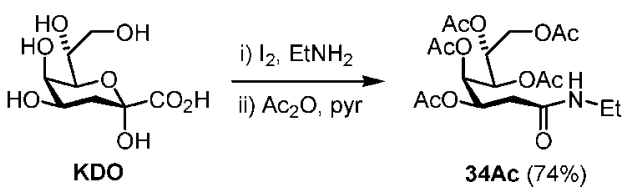

respectively in $73 \%, 61 \%$, and $74 \%$ yields after acetylation. In contrast, $\alpha$-hydroxy acids, e.g., quinic acid, were inert to $\mathrm{I}_{2} /$ $\mathrm{EtNH}_{2}$ under similar conditions. Therefore, this iodine-promoted decarboxylative amidation is unique to $\alpha$-keto acids. In comparison, the conventional conjugation method for unmodified (poly)sialic acid and KDO relies on reductive amination. ${ }^{21,22}$ However, reductive amination of the ketone group is much less effective than that on aldoses. The reductive amination of ketone is further complicated by generation of a new stereocenter.

We also attempted the iodine-promoted decarboxylative amidation reaction of disialic acid (Neu5Ac- $\alpha 2,8-\mathrm{Neu} 5 \mathrm{Ac}$ ) in aqueous ethylamine (70 wt \% solution). The product showed the exact mass at $\mathrm{m} / \mathrm{z} 598.2451[\mathrm{M}-\mathrm{H}]^{-}$(calculated 598.2459 for $\mathrm{C}_{23} \mathrm{H}_{40} \mathrm{~N}_{3} \mathrm{O}_{15}$ ) consistent with the desired glyconamide product. The diagnostic proton signals at $\delta 3.22-3.18$ and 2.39-2.37 were attributable to the amide bond formation (compared with the glyconamide from sialic acid in the Supporting Information). However, we are so far unable to purify or derivatize this glyconamide product for unambiguous structural elucidation.

\section{Conclusion}

We have explored a direct, simple, and efficient one-pot protocol for ligation of aldoses and $\alpha$-keto acids with a variety of amines using iodine as an appropriate oxidant. Because many

(21) (a) Jennings, H. J. Adv. Carbohydr. Chem. Biochem. 1993, 41, 155208. (b) Mieszala, M.; Kogan, G.; Jennings, H. J. Carbohydr. Res. 2003, 338, $167-175$.

(22) (a) Reddy, V. B.; Bartoszewicz, Z.; Rebois, R. V. Cell. Signalling 1996, 8, 35-41. (b) Grimmecke, H. D.; Brade, H. Glycoconj. J. 1998, 15, 555-562.

(23) (a) Mieszala, M.; Kogan, G.; Jennings, H. J. Carbohydr. Res. 2003, 338, 167-175. (b) Seid, R. C., Jr.; Sadoff, J. C. J. Biol. Chem. 1981, 256, 73057310 . 
other functional groups, including the hydroxyl groups and glycoside bonds in carbohydrate molecules, are inert under such mild reaction conditions, the present protocol may be developed as a general method for conjugation of polysaccharides with functional amines without prior protection and modification of the substrates. The iodine-promoted amidation of aldoses was successfully applied to couple with $\alpha$-amino esters, especially in high yields with glycine and lysine, by using the one-pot two-step procedure. However, competitive methanolysis of the intermediate aldonolactone might interfere with the amidation with less nucleophilic $\alpha$-amino esters. We will attempt to find an improved solvent system to circumvent this problem. Extension of the novel decarboxylative amidation method for conjugation of polysialic acid ${ }^{23 a}$ and the KDO-terminated lipopolysaccharides (the lipid A-free LPS ${ }^{23 \mathrm{~b}}$ will also be explored in due course.

\section{Experimental Section}

General Procedure for the Iodine-Promoted Amidation of Carbohydrate Molecules with Primary Amines. A mixture of aldose (or $\alpha$-keto acid, $1.0 \mathrm{mmol}$ ), amine (4 mmol), and iodine (508 mg, $2.0 \mathrm{mmol}$ ) in $5 \mathrm{~mL}$ of water (or aqueous $\mathrm{MeOH}$ solution) was stirred at room temperature for $6-10 \mathrm{~h}$ until the aldose (or $\alpha$-keto acid) was completely consumed as indicated by TLC analysis. A smaller amount of amine $(1.0 \mathrm{mmol})$ was used when the reaction was conducted in the presence of $\mathrm{K}_{2} \mathrm{CO}_{3}(276 \mathrm{mg}, 2$ $\mathrm{mmol})$. The reaction was quenched by addition of $\mathrm{Na}_{2} \mathrm{~S}_{2} \mathrm{O}_{3}(2 \mathrm{~mL}$ of saturated aqueous solution). The mixture was concentrated under reduced pressure to give a crude product of aldonamide.

The crude product was treated with acetic anhydride $(2 \mathrm{~mL})$ and pyridine $(2 \mathrm{~mL})$ at $0-25^{\circ} \mathrm{C}$ for $8 \mathrm{~h}$, then the mixture was partitioned between $1 \mathrm{M} \mathrm{HCl}(30 \mathrm{~mL})$ and $\mathrm{CH}_{2} \mathrm{Cl}_{2}(50 \mathrm{~mL})$. The organic phase was collected, washed with brine $(30 \mathrm{~mL})$, and concentrated under reduced pressure. The residue was purified on a silica gel column by elution with gradients of EtOAc/hexane to afford the desired product of aldonamide peracetate.

General Procedure for Oxidative Amidation of Aldoses with the Methyl Esters of $\boldsymbol{\alpha}$-Amino Acid and Peptides. To a stirred solution of aldose (1.0 mmol), $\mathrm{K}_{2} \mathrm{CO}_{3}(207 \mathrm{mg}, 1.5 \mathrm{mmol})$, and activated molecular sieves in $\mathrm{MeOH}(10 \mathrm{~mL})$ was added iodine (305 mg, $1.2 \mathrm{mmol}$ ) at room temperature under argon for $3 \mathrm{~h}$ until aldose was completely consumed as indicated by TLC analysis. Then $\alpha$-amino acid methyl ester $(1.0-2.0 \mathrm{mmol}$, as the hydrochloric salt) and $\mathrm{K}_{2} \mathrm{CO}_{3}(207 \mathrm{mg}, 1.5 \mathrm{mmol})$ were added, and the mixture was stirred at $40{ }^{\circ} \mathrm{C}$ under argon for $12-16 \mathrm{~h}$ until the product of the first step was completely consumed as indicated by TLC analysis. The reaction was quenched by addition of $\mathrm{Na}_{2} \mathrm{~S}_{2} \mathrm{O}_{3}(2$ $\mathrm{mL}$ of saturated aqueous solution), and the mixture was concentrated under reduced pressure to give a crude product of glycol-conjugate, which was subsequently treated with acetic anhydride $(2 \mathrm{~mL})$ and pyridine $(2 \mathrm{~mL})$ to afford the corresponding peracetate.

$\mathrm{N}$-Ethyl Gluconamide (1a) and $\mathrm{N}$-Ethyl 2,3,4,5,6-O-PentaacetylD-gluconamide (1aAc). A methanolic solution of D-glucose (180 $\mathrm{mg}, 1.0 \mathrm{mmol}$ ) was stirred with ethylamine hydrochloride salt (81.5 $\mathrm{mg}, 1.0 \mathrm{mmol}), \mathrm{I}_{2}(300 \mathrm{mg}, 1.2 \mathrm{mmol})$, and potassium carbonate $(276.0 \mathrm{mg}, 2.0 \mathrm{mmol})$ at room temperature for $6 \mathrm{~h}$. The mixture was filtered, and the filtrate was treated with resin (Dowex 8WX100 , acid form). The supernatant was decanted and concentrated under reduced pressure. The residue was washed with $\mathrm{Et}_{2} \mathrm{O}$ to give a quantitative yield of practically pure amide 1a. $\mathrm{C}_{8} \mathrm{H}_{17} \mathrm{NO}_{6}$; IR $v_{\max }$ (neat) $3369,2933,1644 \mathrm{~cm}^{-1} ;{ }^{1} \mathrm{H}$ NMR $\left(\mathrm{D}_{2} \mathrm{O}, 400 \mathrm{MHz}\right) \delta$ $4.54(1 \mathrm{H}, \mathrm{d}, J=3.6 \mathrm{~Hz}), 4.30(1 \mathrm{H}, \mathrm{t}, J=3.2 \mathrm{~Hz}), 4.06-3.97$ (3 $\mathrm{H}, \mathrm{m}), 3.89(1 \mathrm{H}, \mathrm{dd}, J=11.6,5.6 \mathrm{~Hz}), 3.49(2 \mathrm{H}, \mathrm{q}, J=7.2 \mathrm{~Hz})$, $1.36(3 \mathrm{H}, \mathrm{t}, J=7.2 \mathrm{~Hz}) ;{ }^{13} \mathrm{C}$ NMR $\left(\mathrm{D}_{2} \mathrm{O}, 100 \mathrm{MHz}\right) \delta 173.8$, 73.7, 72.4, 71.5, 70.6, 63.1, 34.9, 14.7; HRMS calcd for $\mathrm{C}_{8} \mathrm{H}_{17} \mathrm{NO}_{6} \mathrm{Na} 246.0948$, found $\mathrm{m} / z$ 246.0948 [M $\left.+\mathrm{Na}\right]^{+}$.
According to the general procedure for oxidative amidation of aldose, an aqueous solution of D-glucose $(180 \mathrm{mg}, 1.0 \mathrm{mmol})$ was stirred with $\mathrm{EtNH}_{2}$ (1 mL of $70 \%$ aqueous solution) and $\mathrm{I}_{2}(508$ $\mathrm{mg}, 2.0 \mathrm{mmol}$ ) at room temperature for $6 \mathrm{~h}$ to give a crude product, which was subsequently treated with $\mathrm{Ac}_{2} \mathrm{O}$ in pyridine to give peracetate 1aAc (368 mg, 85\% yield from glucose). $\mathrm{C}_{18} \mathrm{H}_{27} \mathrm{NO}_{11}$; white solid, mp $189.7-190.7{ }^{\circ} \mathrm{C} ;[\alpha]^{25} \mathrm{D}+19.81$ (c 0.6, EtOAc); IR $v_{\max }$ (neat) $3368,1751,1671 \mathrm{~cm}^{-1} ;{ }^{1} \mathrm{H} \mathrm{NMR}\left(\mathrm{CDCl}_{3}, 400 \mathrm{MHz}\right)$ $\delta 6.08(1 \mathrm{H}, \mathrm{s}), 5.68(1 \mathrm{H}, \mathrm{t}, J=4.8 \mathrm{~Hz}), 5.45(1 \mathrm{H}, \mathrm{dd}, J=6.4$, $5.6 \mathrm{~Hz}), 5.30(1 \mathrm{H}, \mathrm{d}, J=5.6 \mathrm{~Hz}), 5.06-5.02(1 \mathrm{H}, \mathrm{m}), 4.32(1 \mathrm{H}$, $\mathrm{dd}, J=12.4,4.4 \mathrm{~Hz}), 4.14(1 \mathrm{H}, \mathrm{dd}, J=12.4,5.6 \mathrm{~Hz}), 3.37-3.25$ $(2 \mathrm{H}, \mathrm{m}), 2.22(3 \mathrm{H}, \mathrm{s}), 2.13(3 \mathrm{H}, \mathrm{s}), 2.11(3 \mathrm{H}, \mathrm{s}), 2.07(6 \mathrm{H}, \mathrm{s})$, $1.15(3 \mathrm{H}, \mathrm{t}, J=7.2 \mathrm{~Hz}) ;{ }^{13} \mathrm{C} \mathrm{NMR}\left(\mathrm{CDCl}_{3}, 100 \mathrm{MHz}\right) \delta 169.8$, $169.1(2 \times), 168.9,168.4,165.1,71.6,69.3,69.0,68.6,61.5,34.6$, $21.0(4 \times), 20.7,14.9$; MS (ESI) calcd for $\mathrm{C}_{18} \mathrm{H}_{28} \mathrm{NO}_{11} 434$, found $\mathrm{m} / z 434[\mathrm{M}+\mathrm{H}]^{+}$; HRMS (ESI) calcd for $\mathrm{C}_{18} \mathrm{H}_{27} \mathrm{NO}_{11} \mathrm{Na} 456.1476$, found $\mathrm{m} / \mathrm{z}, 456.1471[\mathrm{M}+\mathrm{Na}]^{+}$.

$\mathrm{N}$-Allyl 2,3,4,5,6-O-pentaacetyl-D-gluconamide (1eAc). According to the general procedure for oxidative amidation of aldose, an aqueous solution of D-glucose $(180 \mathrm{mg}, 1.0 \mathrm{mmol})$ was stirred with allylamine (228 mg, $4 \mathrm{mmol})$ and $\mathrm{I}_{2}(508 \mathrm{mg}, 2.0 \mathrm{mmol})$ at room temperature for $8 \mathrm{~h}$ to give a crude product of $\mathrm{N}$-allyl gluconamide, which was subsequently treated with $\mathrm{Ac}_{2} \mathrm{O}$ in pyridine to give compound 1eAc (379 mg, $85 \%$ yield). $\mathrm{C}_{19} \mathrm{H}_{27} \mathrm{NO}_{11}$; white solid, mp $160.0-161.5^{\circ} \mathrm{C} ;[\alpha]^{25}{ }_{\mathrm{D}}+10.18\left(\mathrm{c} 0.3\right.$, EtOAc); IR $v_{\max }$ (neat) $3265,1750,1659 \mathrm{~cm}^{-1} ;{ }^{1} \mathrm{H}$ NMR $\left(\mathrm{CDCl}_{3}, 400 \mathrm{MHz}\right) \delta 6.19(1 \mathrm{H}$, br), 5.83-5.73 (1 H, m), $5.67(1 \mathrm{H}, \mathrm{t}, J=5.6 \mathrm{~Hz}), 5.44(1 \mathrm{H}, \mathrm{t}, J$ $=5.6 \mathrm{~Hz}), 5.32(1 \mathrm{H}, \mathrm{d}, J=4.8 \mathrm{~Hz}), 5.20-5.12(2 \mathrm{H}, \mathrm{m})$, 5.04-5.00 (1 H, m), $4.30(1 \mathrm{H}, \mathrm{dd}, J=12,4.4 \mathrm{~Hz}), 4.11(1 \mathrm{H}, \mathrm{dd}$, $J=12,5.2 \mathrm{~Hz}), 3.94-3.80(2 \mathrm{H}, \mathrm{m}), 2.20(3 \mathrm{H}, \mathrm{s}), 2.10(3 \mathrm{H}, \mathrm{s})$, $2.08(3 \mathrm{H}, \mathrm{s}), 2.04(6 \mathrm{H}, \mathrm{s}) ;{ }^{13} \mathrm{C} \mathrm{NMR}\left(\mathrm{CDCl}_{3}, 100 \mathrm{MHz}\right) \delta 169.8$, $169.1(2 \times), 168.9,168.4,165.2,132.9,116.4,71.6,69.3,69.0$, $68.6,61.5,41.9,21.1(2 \times), 21.0(2 \times), 20.8$; HRMS calcd for $\mathrm{C}_{19} \mathrm{H}_{28} \mathrm{NO}_{11}$ 446.1657, found $\mathrm{m} / z$ 446.1625 [M $\left.+\mathrm{H}\right]^{+}$.

$N, N^{\prime}$-Hexylene Bis(2,3,4,5,6-pentaacetoxyhexamide) (1gAc). According to the general procedure for oxidative amidation of aldose, a methanolic solution of D-glucose $(180 \mathrm{mg}, 1.0 \mathrm{mmol})$ was stirred with 1,6-diaminohexane (232 mg, $2.0 \mathrm{mmol})$ and $\mathrm{I}_{2}(508 \mathrm{mg}, 2.0$ $\mathrm{mmol}$ ) at room temperature for $10 \mathrm{~h}$ to give a crude product, which was subsequently treated with $\mathrm{Ac}_{2} \mathrm{O}$ in pyridine to give compound 1 gAc (440 mg, 98\% yield). $\mathrm{C}_{38} \mathrm{H}_{56} \mathrm{~N}_{2} \mathrm{O}_{22}$; white foam; $[\alpha]^{25}{ }_{\mathrm{D}}+27.40$ (c $1.5, \mathrm{CH}_{2} \mathrm{Cl}_{2}$ ); IR $v_{\max }$ (neat) $3375,1751,1677 \mathrm{~cm}^{-1}$; ${ }^{1} \mathrm{H}$ NMR $\left(\mathrm{CDCl}_{3}, 400 \mathrm{MHz}\right) \delta 6.26(2 \mathrm{H}, \mathrm{t}, J=5.2 \mathrm{~Hz}), 5.67(2 \mathrm{H}, \mathrm{t}, J=$ $5.6 \mathrm{~Hz}), 5.44(2 \mathrm{H}, \mathrm{dd}, J=6.4,5.2 \mathrm{~Hz}), 5.28(2 \mathrm{H}, \mathrm{d}, J=5.6 \mathrm{~Hz})$, 5.06-5.02 (2 H, m), $4.32(2 \mathrm{H}, \mathrm{dd}, J=12,4.0 \mathrm{~Hz}), 4.13(2 \mathrm{H}, \mathrm{dd}$, $J=12,5.6 \mathrm{~Hz}), 3.27-3.21(4 \mathrm{H}, \mathrm{m}), 2.21(6 \mathrm{H}, \mathrm{s}), 2.12(6 \mathrm{H}, \mathrm{s})$, $2.10(6 \mathrm{H}, \mathrm{s}), 2.06(12 \mathrm{H}, \mathrm{s}), 1.49(4 \mathrm{H}$, br m $), 1.30\left(4 \mathrm{H}\right.$, br m); ${ }^{13} \mathrm{C}$ NMR $\left(\mathrm{CDCl}_{3}, 100 \mathrm{MHz}\right) \delta 170.3(2 \times), 169.5(4 \times), 169.4(2 \times)$, $168.9(2 \times), 165.8(2 \times), 71.6(2 \times), 69.3(2 \times), 68.9(2 \times), 68.6(2 \times)$, $61.4(2 \times), 38.8(2 \times), 29.1(2 \times), 25.6(2 \times), 20.7(8 \times), 20.4(2 \times)$; HRMS (ESI) calcd for $\mathrm{C}_{38} \mathrm{H}_{57} \mathrm{~N}_{2} \mathrm{O}_{22} 893.3397$, found $\mathrm{m} / z, 893.3391$ $[\mathrm{M}+\mathrm{H}]^{+}$.

$N$-Hexadecyl $2,2^{\prime}, 2^{\prime \prime}, 3,3^{\prime}, 3^{\prime \prime}, 4^{\prime \prime}, 5,6,6^{\prime}, 6^{\prime \prime}$ - $O$-Undecaacetylmaltotrionamide (11cAc). According to the general procedure for oxidative amidation of aldose, an methanoic solution of D-maltotriose (504 $\mathrm{mg}, 1.0 \mathrm{mmol}$ ) was stirred with cetylamine (964 mg, $4 \mathrm{mmol}$ ) and $\mathrm{I}_{2}(508 \mathrm{mg}, 2.0 \mathrm{mmol})$ at room temperature for $10 \mathrm{~h}$ to give a crude product, which was subsequently treated with $\mathrm{Ac}_{2} \mathrm{O}$ in pyridine to give compound 11cAc (1.10 g, 91\% yield). $\mathrm{C}_{56} \mathrm{H}_{87} \mathrm{NO}_{27}$; white foam, $[\alpha]^{25}+78.11$ (c 1.06, EtOAc); IR $v_{\max }$ (neat) 3637, 3270, 1754, 1672, $1639 \mathrm{~cm}^{-1} ;{ }^{1} \mathrm{H}$ NMR $\left(\mathrm{CDCl}_{3}, 400 \mathrm{MHz}\right) \delta 6.21(1 \mathrm{H}$, $\mathrm{t}, J=5.6 \mathrm{~Hz}), 5.53-5.36(5 \mathrm{H}, \mathrm{m}), 5.24(1 \mathrm{H}, \mathrm{d}, J=3.6 \mathrm{~Hz})$, $5.17-5.15(1 \mathrm{H}, \mathrm{m}), 5.07(1 \mathrm{H}, \mathrm{t}, J=10.4 \mathrm{~Hz}), 4.87(2 \mathrm{H}, \mathrm{dd}, J$ $=10.4,3.6 \mathrm{~Hz}), 4.65(1 \mathrm{H}, \mathrm{dd}, J=12.0,2.4 \mathrm{~Hz}), 4.48(1 \mathrm{H}, \mathrm{d}, J$ $=12.0 \mathrm{~Hz}), 4.28-3.94(8 \mathrm{H}, \mathrm{m}), 3.21(2 \mathrm{H}, \mathrm{m}), 2.17(3 \mathrm{H}, \mathrm{s}), 2.15$ (3 H, s), $2.11(3 \mathrm{H}, \mathrm{s}), 2.10(6 \mathrm{H}, \mathrm{s}), 2.09(3 \mathrm{H}, \mathrm{s}), 2.08(3 \mathrm{H}, \mathrm{s})$, $2.05(3 \mathrm{H}, \mathrm{s}), 2.03(3 \mathrm{H}, \mathrm{s}), 2.01(6 \mathrm{H}, \mathrm{s}), 1.44(2 \mathrm{H}$, br m) 1.25 $\left(26 \mathrm{H}\right.$, br m), $0.88(3 \mathrm{H}, \mathrm{t}, J=6 \mathrm{~Hz}) ;{ }^{13} \mathrm{C} \mathrm{NMR}\left(\mathrm{CDCl}_{3}, 100 \mathrm{MHz}\right)$ $\delta 170.7,170.3(2 \times), 170.2,169.9,169.7,169.5(2 \times), 169.4,169.2$, 
$169.0,166.2,97.6,95.5,77.1,72.6,71.8,71.3,70.9,70.8,70.5$, $69.9,69.3,68.8,68.3,67.9,62.5,62.4,61.3,53.4,39.8,39.5,31.9$, $29.7(2 \times), 29.6(2 \times), 29.4,29.3(2 \times), 26.9,26.8,23.3,22.7,21.0$, $20.9(2 \times), 20.8,20.7(6 \times), 20.6,14.2$; MS calcd for $\mathrm{C}_{56} \mathrm{H}_{88} \mathrm{NO}_{27}$ 1206, found $m / z, 1206[\mathrm{M}+\mathrm{H}]^{+}$; HRMS calcd for $\mathrm{C}_{56} \mathrm{H}_{88} \mathrm{NO}_{27}$ 1206.5538, found $\mathrm{m} / \mathrm{z}, 1206.5537[\mathrm{M}+\mathrm{H}]^{+}$.

$\mathrm{N}$-Gluconylglycine Methyl Ester (12) and $\mathrm{N}$-(2,3,4,5,6-O-Pentaacetylgluconyl)glycine Methyl Ester (12Ac). According to the general procedure for oxidative amidation of aldose, a methanolic solution of D-glucose $(180 \mathrm{mg}, 1.0 \mathrm{mmol})$ was stirred with $\mathrm{K}_{2} \mathrm{CO}_{3}$ (207 mg, $1.5 \mathrm{mmol})$ and $\mathrm{I}_{2}(305 \mathrm{mg}, 1.2 \mathrm{mmol})$ in the presence of activated molecular sieves at room temperature under argon for $3 \mathrm{~h}$. Then the $\mathrm{HCl}$ salt of glycine methyl ester $(251 \mathrm{mg}, 2.0 \mathrm{mmol})$ and $\mathrm{K}_{2} \mathrm{CO}_{3}(207 \mathrm{mg}, 1.5 \mathrm{mmol})$ were added, and the mixture was stirred at $40{ }^{\circ} \mathrm{C}$ under argon for $12 \mathrm{~h}$. The mixture was filtrated, and subsequently purified by flash chromatography (RP-18; water) to give the title compound ( $256 \mathrm{mg}, 96 \%$ yield). $\mathrm{C}_{9} \mathrm{H}_{17} \mathrm{NO}_{8}$; yellow solid (hygroscopic); $[\alpha]^{25}+45.97$ (c 2.6, MeOH); IR $v_{\max }$ (neat) 3362, 1739, $1658 \mathrm{~cm}^{-1}$; ${ }^{1} \mathrm{H}$ NMR $\left(\mathrm{D}_{2} \mathrm{O}, 400 \mathrm{MHz}\right) \delta 4.37(1 \mathrm{H}, \mathrm{d}$, $J=4 \mathrm{~Hz}), 4.13-4.01(3 \mathrm{H}, \mathrm{m}), 3.83-3.80(1 \mathrm{H}, \mathrm{m}), 3.77-3.72$ $(5 \mathrm{H}, \mathrm{m}), 3.66-3.62(1 \mathrm{H}, \mathrm{m}) ;{ }^{13} \mathrm{C}$ NMR $\left(\mathrm{D}_{2} \mathrm{O}, 100 \mathrm{MHz}\right) \delta 175.0$, 171.9, 73.4, 72.6, 71.2, 70.6, 62.8, 53.0, 41.1; HRMS (ESI) calcd for $\mathrm{C}_{9} \mathrm{H}_{17} \mathrm{NO}_{8} \mathrm{~K} 306.0585$, found $\mathrm{m} / z 306.0580[\mathrm{M}+\mathrm{K}]^{+}$.

According to the general procedure for oxidative amidation of aldose, a methanolic solution of D-glucose $(180 \mathrm{mg}, 1.0 \mathrm{mmol})$ was stirred with $\mathrm{K}_{2} \mathrm{CO}_{3}(207 \mathrm{mg}, 1.5 \mathrm{mmol})$ and $\mathrm{I}_{2}(305 \mathrm{mg}, 1.2$ $\mathrm{mmol}$ ) in the presence of activated molecular sieves at room temperature under argon for $3 \mathrm{~h}$. Then the $\mathrm{HCl}$ salt of glycine methyl ester ( $251 \mathrm{mg}, 2.0 \mathrm{mmol})$ and $\mathrm{K}_{2} \mathrm{CO}_{3}(207 \mathrm{mg}, 1.5 \mathrm{mmol})$ were added, and the mixture was stirred at $40{ }^{\circ} \mathrm{C}$ under argon for $12 \mathrm{~h}$. The mixture was concentrated by rotary evaporation to give a crude product, which was subsequently treated with $\mathrm{Ac}_{2} \mathrm{O}$ in pyridine and purified by flash chromatography (silica gel; EtOAc/ hexane, 2:1) to give compound 12Ac (448 mg, 94\% yield).

Alternatively, a methanolic solution of D-glucose (180 mg, 1.0 mmol) was stirred with the $\mathrm{HCl}$ salt of glycine methyl ester (500 $\mathrm{mg}, 4.0 \mathrm{mmol})$ and $\mathrm{I}_{2}(508 \mathrm{mg}, 2.0 \mathrm{mmol})$ in the presence of $\mathrm{K}_{2} \mathrm{CO}_{3}$ $(552 \mathrm{mg}, 4.0 \mathrm{mmol})$ at room temperature for $10 \mathrm{~h}$ to give a crude product, which was subsequently treated with $\mathrm{Ac}_{2} \mathrm{O}$ in pyridine to give compound 12Ac (225 mg, 50\% yield). $\mathrm{C}_{19} \mathrm{H}_{27} \mathrm{NO}_{13}$; pale yellow solid, mp $175.3-177.5{ }^{\circ} \mathrm{C} ;[\alpha]^{25} \mathrm{D}+6.86$ (c 0.3, EtOAc); IR $v_{\max }$ (neat) $3361,1750,1681 \mathrm{~cm}^{-1} ;{ }^{1} \mathrm{H} \mathrm{NMR}\left(\mathrm{CDCl}_{3}, 400 \mathrm{MHz}\right)$ $\delta 6.63(1 \mathrm{H}$, br s), $5.68(1 \mathrm{H}, \mathrm{t}, J=4.8 \mathrm{~Hz}), 5.48(1 \mathrm{H}, \mathrm{dd}, J=$ 6.4, $4.8 \mathrm{~Hz}), 5.38(1 \mathrm{H}, \mathrm{d}, J=5.2 \mathrm{~Hz}), 5.07-5.03(1 \mathrm{H}, \mathrm{m}), 4.32$ $(1 \mathrm{H}, \mathrm{dd}, J=12.4,4.4 \mathrm{~Hz}), 4.16-4.08(2 \mathrm{H}, \mathrm{m}), 3.97(1 \mathrm{H}, \mathrm{dd}, J$ $=18,4.8 \mathrm{~Hz}), 3.77(3 \mathrm{H}, \mathrm{s}), 2.24(3 \mathrm{H}, \mathrm{s}), 2.13(3 \mathrm{H}, \mathrm{s}), 2.11(3$ $\mathrm{H}, \mathrm{s}), 2.10(3 \mathrm{H}, \mathrm{s}), 2.06(3 \mathrm{H}, \mathrm{s}) ;{ }^{13} \mathrm{C} \mathrm{NMR}\left(\mathrm{CDCl}_{3}, 100 \mathrm{MHz}\right) \delta$ 170.4, 169.7, 169.6, $169.4(2 \times)$, 169.2, 166.2, 71.6, 69.4, 68.6, 68.6, 61.4, 52.5, 41.0, 20.9, $20.8(3 \times)$, 20.6; HRMS (ESI) calcd $\mathrm{C}_{19} \mathrm{H}_{28} \mathrm{NO}_{13} 478.1555$, found $\mathrm{m} / z$ 478.1536 [M + H] ${ }^{+}$.

$\mathrm{N}$-(2,3,4,5,6-O-Pentaacetylgluconyl)-L-valine Methyl Ester (13Ac). According to the general procedure for oxidative amidation of aldose, a methanolic solution of D-glucose $(180 \mathrm{mg}, 1.0 \mathrm{mmol})$ was stirred with the $\mathrm{HCl}$ salt of L-valine methyl ester $(671 \mathrm{mg}, 4.0$ $\mathrm{mmol})$ and $\mathrm{I}_{2}(508 \mathrm{mg}, 2.0 \mathrm{mmol})$ in the presence of $\mathrm{K}_{2} \mathrm{CO}_{3}(552$ $\mathrm{mg}, 4.0 \mathrm{mmol}$ ) at room temperature for $10 \mathrm{~h}$ to give a crude product, which was subsequently treated with $\mathrm{Ac}_{2} \mathrm{O}$ in pyridine to give compound 13Ac (364 mg, 70\% yield). $\mathrm{C}_{22} \mathrm{H}_{33} \mathrm{NO}_{13}$; white solid, mp $130.5-132.0{ }^{\circ} \mathrm{C} ;[\alpha]^{25} \mathrm{D}+29.43\left(c 0.5, \mathrm{CH}_{2} \mathrm{Cl}_{2}\right)$; IR $v_{\max }$ (neat) $3297,1757,1668 \mathrm{~cm}^{-1} ;{ }^{1} \mathrm{H}$ NMR $\left(\mathrm{CDCl}_{3}, 400 \mathrm{MHz}\right) \delta 6.47(1 \mathrm{H}$, $\mathrm{d}, J=8.8 \mathrm{~Hz}), 5.68(1 \mathrm{H}, \mathrm{dd}, J=5.6,4.4 \mathrm{~Hz}), 5.46(1 \mathrm{H}, \mathrm{t}, J=$ $5.6 \mathrm{~Hz}), 5.37(1 \mathrm{H}, \mathrm{d}, J=4.4 \mathrm{~Hz}), 5.02(1 \mathrm{H}, \mathrm{dd}, J=10.4,5.2$ $\mathrm{Hz}), 4.52(1 \mathrm{H}, \mathrm{dd}, J=8.8,4.4 \mathrm{~Hz}), 4.31(1 \mathrm{H}, \mathrm{dd}, J=12,4.4$ $\mathrm{Hz}), 4.16(1 \mathrm{H}, \mathrm{dd}, J=12,5.6 \mathrm{~Hz}), 3.73(3 \mathrm{H}, \mathrm{s}), 2.25(3 \mathrm{H}, \mathrm{s})$, 2.23-2.12 (1 H, m), $2.11(6 \mathrm{H}, \mathrm{s}), 2.07(3 \mathrm{H}, \mathrm{s}), 2.05(3 \mathrm{H}, \mathrm{s})$, $0.91(3 \mathrm{H}, \mathrm{d}, J=6.8 \mathrm{~Hz}), 0.86(3 \mathrm{H}, \mathrm{d}, J=6.8 \mathrm{~Hz}) ;{ }^{13} \mathrm{C} \mathrm{NMR}$ $\left(\mathrm{CDCl}_{3}, 100 \mathrm{MHz}\right) \delta 171.1,169.8,169.1(2 \times), 168.9,168.6,165.6$, 72.3, 72.2, 69.6, 68.7, 61.4, 56.9, 52.4, 31.4, 21.1 (2×), 20.9, 20.8,
19.2, $17.6(2 \times)$; HRMS (ESI) calcd $\mathrm{C}_{22} \mathrm{H}_{33} \mathrm{NO}_{13} \mathrm{Na} 542.1844$, found $\mathrm{m} / \mathrm{z}, 542.1836[\mathrm{M}+\mathrm{Na}]^{+}$.

$\mathrm{N}$-(2,3,4,5,6-O -Pentaacetyl-D-gluconyl)- $O$-acetyl-L-serine Methyl Ester (14Ac). According to the general procedure for oxidative amidation of aldose, a methanolic solution of D-glucose $(180 \mathrm{mg}$, $1.0 \mathrm{mmol}$ ) was stirred with $\mathrm{K}_{2} \mathrm{CO}_{3}(207 \mathrm{mg}, 1.5 \mathrm{mmol})$ and $\mathrm{I}_{2}(305$ $\mathrm{mg}, 1.2 \mathrm{mmol})$ in the presence of activated molecular sieves at room temperature under argon for $3 \mathrm{~h}$. Then the $\mathrm{HCl}$ salt of $\mathrm{L}$-serine methyl ester $(311 \mathrm{mg}, 2.0 \mathrm{mmol})$ and $\mathrm{K}_{2} \mathrm{CO}_{3}(207 \mathrm{mg}, 1.5 \mathrm{mmol})$ were added, and the mixture was stirred at $40{ }^{\circ} \mathrm{C}$ under argon for $16 \mathrm{~h}$. The mixture was concentrated by rotary evaporation to give a crude product, which was subsequently treated with $\mathrm{Ac}_{2} \mathrm{O}$ in pyridine and purified by flash chromatography (silica gel; EtOAc/ hexane, 1:1) to give compound 14Ac (300 $\mathrm{mg}, 55 \%$ yield). $\mathrm{C}_{22} \mathrm{H}_{31} \mathrm{NO}_{15}$; yellow foam; $[\alpha]^{25}+28.08\left(c 3.9, \mathrm{CH}_{2} \mathrm{Cl}_{2}\right)$; IR $v_{\max }$ (neat) $3360,1747,1694 \mathrm{~cm}^{-1} ;{ }^{1} \mathrm{H} \mathrm{NMR}\left(\mathrm{CDCl}_{3}, 400 \mathrm{MHz}\right) \delta 6.87$ $(1 \mathrm{H}, \mathrm{d}, J=7.6 \mathrm{~Hz}), 5.70(1 \mathrm{H}, \mathrm{dd}, J=5.8,4.6 \mathrm{~Hz}), 5.45(1 \mathrm{H}$, $\mathrm{t}, J=5.8 \mathrm{~Hz}), 5.38(1 \mathrm{H}, \mathrm{d}, J=4.4 \mathrm{~Hz}), 5.01(1 \mathrm{H}, \mathrm{dd}, J=10.6$, $5.0 \mathrm{~Hz}), 4.80-4.76(1 \mathrm{H}, \mathrm{m}), 4.48(1 \mathrm{H}, \mathrm{dd}, J=11.8,4.8 \mathrm{~Hz})$, 4.33-4.29 (2 H, m), $4.14(1 \mathrm{H}, \mathrm{dd}, J=11.8,5.2 \mathrm{~Hz}), 3.76(3 \mathrm{H}$, s), $2.26(3 \mathrm{H}, \mathrm{s}), 2.10(6 \mathrm{H}, \mathrm{s}), 2.09(3 \mathrm{H}, \mathrm{s}), 2.05(3 \mathrm{H}, \mathrm{s}), 2.04$ (3 $\mathrm{H}, \mathrm{s}) ;{ }^{13} \mathrm{C} \mathrm{NMR}\left(\mathrm{CDCl}_{3}, 100 \mathrm{MHz}\right) \delta 170.6,170.0,169.3(2 \times)$, 169.2, 168.9, 168.5, 166.0, 71.7, 69.4, $68.5(2 \times), 62.9,61.1,52.7$, $51.8,20.6(2 \times), 20.5(2 \times), 20.4,20.3$; HRMS (ESI) calcd for $\mathrm{C}_{22} \mathrm{H}_{32} \mathrm{NO}_{15} 550.1766$, found $\mathrm{m} / \mathrm{z} 550.1765[\mathrm{M}+\mathrm{H}]^{+}$.

$\mathrm{N}$-(2,3,4,5,6-O-Pentaacetyl-D-gluconyl)-L-tyrosine Methyl Ester (15Ac). According to the general procedure for oxidative amidation of aldose, a methanolic solution of D-glucose $(180 \mathrm{mg}, 1.0 \mathrm{mmol})$ was stirred with $\mathrm{K}_{2} \mathrm{CO}_{3}(207 \mathrm{mg}, 1.5 \mathrm{mmol})$ and $\mathrm{I}_{2}(254 \mathrm{mg}, 1.0$ $\mathrm{mmol}$ ) in the presence of activated molecular sieves at room temperature under argon for $3 \mathrm{~h}$. Then the $\mathrm{HCl}$ salt of L-tyrosine methyl ester ( $463 \mathrm{mg}, 2.0 \mathrm{mmol})$ and $\mathrm{K}_{2} \mathrm{CO}_{3}(207 \mathrm{mg}, 1.5 \mathrm{mmol})$ were added, and the mixture was stirred at $40{ }^{\circ} \mathrm{C}$ under argon for $14 \mathrm{~h}$. The mixture was concentrated by rotary evaporation to give a crude product, which was subsequently treated with $\mathrm{Ac}_{2} \mathrm{O}$ in pyridine and purified by flash chromatography (silica gel; EtOAc/ $\left.\mathrm{MeOH} / \mathrm{Et}_{3} \mathrm{~N}, 98: 1: 1\right)$ to give compound 15Ac (388 mg, 62\% yield). $\mathrm{C}_{28} \mathrm{H}_{35} \mathrm{NO}_{15}$; yellow solid, mp $121.3-122.5{ }^{\circ} \mathrm{C} ;[\alpha]^{25} \mathrm{D}+22.98(c$ 2.4, $\mathrm{CH}_{2} \mathrm{Cl}_{2}$ ); IR $v_{\max }$ (neat) $3344,1749,1688 \mathrm{~cm}^{-1} ;{ }^{1} \mathrm{H} \mathrm{NMR}$ $\left(\mathrm{CDCl}_{3}, 400 \mathrm{MHz}\right) \delta 7.03-6.98(4 \mathrm{H}, \mathrm{m}), 6.37(1 \mathrm{H}, \mathrm{d}, J=8.0$ $\mathrm{Hz}), 5.64(1 \mathrm{H}, \mathrm{dd}, J=5.6,3.6 \mathrm{~Hz}), 5.43(1 \mathrm{H}, \mathrm{d}, J=6.0 \mathrm{~Hz})$, $5.41(1 \mathrm{H}, \mathrm{t}, J=2.4 \mathrm{~Hz}), 5.02-4.98(1 \mathrm{H}, \mathrm{m}), 4.87-4.83(1 \mathrm{H}$, m), $4.29(1 \mathrm{H}, \mathrm{dd}, J=12.1,4.4 \mathrm{~Hz}), 4.13(1 \mathrm{H}, \mathrm{dd}, J=12.1,5.4$ $\mathrm{Hz}), 3.75(3 \mathrm{H}, \mathrm{s}), 3.14$ (1 H, dd, $J=14.1,5.0 \mathrm{~Hz}), 3.07(1 \mathrm{H}, \mathrm{dd}$, $J=14.1,6.0 \mathrm{~Hz}), 2.29(3 \mathrm{H}, \mathrm{s}), 2.12(3 \mathrm{H}, \mathrm{s}), 2.11(3 \mathrm{H}, \mathrm{s}), 2.08$ (3 H, s), $2.04(3 \mathrm{H}, \mathrm{s}), 2.02(3 \mathrm{H}, \mathrm{s}) ;{ }^{13} \mathrm{C} \mathrm{NMR}\left(\mathrm{CDCl}_{3}, 100 \mathrm{MHz}\right)$ $\delta$ 170.8, 170.3, 169.6, 169.4, 169.3, 169.1, 169.0, 165.8, 149.7, 132.6, $130.1(2 \times), 121.7(2 \times), 72.0,69.6,68.8,68.7,61.3,52.6$, 52.5, 36.8, 21.2, 20.82, 20.78, 20.74, 20.65, 20.5; HRMS (ESI) calcd for $\mathrm{C}_{28} \mathrm{H}_{35} \mathrm{NO}_{15} \mathrm{Na} 648.1899$, found $\mathrm{m} / \mathrm{z} 648.1904[\mathrm{M}+\mathrm{Na}]^{+}$.

$\mathrm{N}$-(2,3,4,5,6-O-Pentaacetyl-D-gluconyl)-L-methionine Methyl Ester (16Ac). According to the general procedure for oxidative amidation of aldose, a methanolic solution of D-glucose $(180 \mathrm{mg}$, $1.0 \mathrm{mmol})$ was stirred with $\mathrm{K}_{2} \mathrm{CO}_{3}(207 \mathrm{mg}, 1.5 \mathrm{mmol})$ and $\mathrm{I}_{2}(254$ $\mathrm{mg}, 1.0 \mathrm{mmol}$ ) in the presence of activated molecular sieves at room temperature under argon for $3 \mathrm{~h}$. Then the $\mathrm{HCl}$ salt of L-methionine methyl ester (400 mg, $2.0 \mathrm{mmol})$ and $\mathrm{K}_{2} \mathrm{CO}_{3}(207$ $\mathrm{mg}, 1.5 \mathrm{mmol}$ ) were added, and the mixture was stirred at $40{ }^{\circ} \mathrm{C}$ under argon for $17 \mathrm{~h}$. The mixture was concentrated by rotary evaporation to give a crude product, which was subsequently treated with $\mathrm{Ac}_{2} \mathrm{O}$ in pyridine and purified by flash chromatography (silica gel; EtOAc/hexane, $1: 1)$ to give compound 16Ac (259 mg, $47 \%$ yield). $\mathrm{C}_{22} \mathrm{H}_{33} \mathrm{NO}_{13} \mathrm{~S}$; white foam; $[\alpha]^{25}{ }_{\mathrm{D}}+26.72\left(c 1.5, \mathrm{CH}_{2} \mathrm{Cl}_{2}\right)$; IR $v_{\max }$ (neat) $3358,1749,1687 \mathrm{~cm}^{-1} ;{ }^{1} \mathrm{H} \mathrm{NMR}\left(\mathrm{CDCl}_{3}, 400 \mathrm{MHz}\right)$ $\delta 6.85(1 \mathrm{H}, \mathrm{d}, J=7.6 \mathrm{~Hz}), 5.68(1 \mathrm{H}, \mathrm{t}, J=4.8 \mathrm{~Hz}), 5.44(1 \mathrm{H}$, $\mathrm{t}, J=5.6 \mathrm{~Hz}), 5.34(1 \mathrm{H}, \mathrm{d}, J=4.4 \mathrm{~Hz}), 5.02(1 \mathrm{H}, \mathrm{dd}, J=9.6$, $5.6 \mathrm{~Hz}), 4.69-4.64(1 \mathrm{H}, \mathrm{m}), 4.30(1 \mathrm{H}, \mathrm{dd}, J=12.1,4.2 \mathrm{~Hz})$, $4.14(1 \mathrm{H}, \mathrm{dd}, J=12.1,5.6 \mathrm{~Hz}), 3.74(3 \mathrm{H}, \mathrm{s}), 2.48(2 \mathrm{H}, \mathrm{t}, J=$ $7.2 \mathrm{~Hz}), 2.23(3 \mathrm{H}, \mathrm{s}), 2.20-2.12(1 \mathrm{H}, \mathrm{m}), 2.10$ (6 H, s), 2.08 (3 
$\mathrm{H}, \mathrm{s}), 2.07$ (3 H, s), $2.04(3 \mathrm{H}, \mathrm{s}), 2.02-1.95(1 \mathrm{H}, \mathrm{m}) ;{ }^{13} \mathrm{C} \mathrm{NMR}$ $\left(\mathrm{CDCl}_{3}, 100 \mathrm{MHz}\right) \delta 171.4,170.3,169.52,169.45,169.4,169.0$, 165.9, 71.8, 69.4, 68.64, 68.59, 61.2, 52.6, 51.5, 30.8, 29.8, 20.74, $20.68(3 \times)$, 20.4, 15.4; HRMS (ESI) calcd for $\mathrm{C}_{22} \mathrm{H}_{33} \mathrm{NO}_{13} \mathrm{SNa}$ 574.1565 , found $\mathrm{m} / \mathrm{z} 574.1538[\mathrm{M}+\mathrm{Na}]^{+}$.

$\mathrm{N}$-(2,3,4,5,6-O -Pentaacetyl-D-gluconyl)-S -acetyl-L-cysteine Methyl Ester (17Ac). According to the general procedure for oxidative amidation of aldose, a methanolic solution of D-glucose $(90 \mathrm{mg}$, $0.5 \mathrm{mmol})$ was stirred with $\mathrm{K}_{2} \mathrm{CO}_{3}(138 \mathrm{mg}, 1.0 \mathrm{mmol})$ and $\mathrm{I}_{2}(127$ $\mathrm{mg}, 0.5 \mathrm{mmol}$ ) at $70{ }^{\circ} \mathrm{C}$ under argon for $20 \mathrm{~min}$. Then the $\mathrm{HCl}$ salt of L-cysteine methyl ester (103 $\mathrm{mg}, 0.6 \mathrm{mmol})$ was added, and the mixture was stirred at $70{ }^{\circ} \mathrm{C}$ under argon for $5 \mathrm{~h}$ to complete the amidation as shown by TLC analysis. The mixture was concentrated by rotary evaporation to give a crude product, which was subsequently treated with $\mathrm{Ac}_{2} \mathrm{O}$ in pyridine and purified by flash chromatography (silica gel; EtOAc/hexane, 1:1) to give compound 17Ac (120 mg, $42 \%$ yield). $\mathrm{C}_{22} \mathrm{H}_{31} \mathrm{NO}_{14} \mathrm{~S}$; white foam; $[\alpha]^{25}$ +13.33 (c 2.2, EtOAc); IR $v_{\max }$ (neat) $3363,1750,1691 \mathrm{~cm}^{-1} ;{ }^{1} \mathrm{H}$ NMR $\left(\mathrm{CDCl}_{3}, 400 \mathrm{MHz}\right) \delta 6.82(1 \mathrm{H}, \mathrm{d}, J=8.0 \mathrm{~Hz}), 5.71(1 \mathrm{H}$, $\mathrm{dd}, J=6.0,3.6 \mathrm{~Hz}), 5.46-5.43(2 \mathrm{H}, \mathrm{m}), 5.01-4.97(1 \mathrm{H}, \mathrm{m})$, 4.72-4.67 (1 H, m), $4.31(1 \mathrm{H}, \mathrm{dd}, J=12.1,4.8 \mathrm{~Hz}), 4.14(1 \mathrm{H}$, dd, $J=12.1,5.4 \mathrm{~Hz}), 3.73(3 \mathrm{H}, \mathrm{s}), 3.35(1 \mathrm{H}, \mathrm{dd}, J=14.5,8.8$ $\mathrm{Hz}), 3.21(1 \mathrm{H}, \mathrm{dd}, J=14.5,3.4 \mathrm{~Hz}), 2.35(3 \mathrm{H}, \mathrm{s}), 2.30(3 \mathrm{H}, \mathrm{s})$, $2.11(3 \mathrm{H}, \mathrm{s}), 2.09(6 \mathrm{H}, \mathrm{s}), 2.03(3 \mathrm{H}, \mathrm{s}) ;{ }^{13} \mathrm{C} \mathrm{NMR}\left(\mathrm{CDCl}_{3}, 100\right.$ MHz) $\delta 196.4,170.2,169.6,169.5,169.4,169.3,169.0,166.4$, $71.7,69.7,68.9,68.7,61.1,52.76,52.75,30.4,30.0,20.8,20.74$, $20.72(2 \times), 20.5$; HRMS (ESI) calcd for $\mathrm{C}_{22} \mathrm{H}_{31} \mathrm{NO}_{14} \mathrm{SNa} 588.1357$, found $\mathrm{m} / \mathrm{z}, 588.1328[\mathrm{M}+\mathrm{Na}]^{+}$.

$N$-(2,3,4,5,6-O-Pentaacetyl-D-gluconyl)-L-histidine Methyl Ester (18Ac). According to the general procedure for oxidative amidation of aldose, a methanolic solution of D-glucose $(180 \mathrm{mg}, 1.0 \mathrm{mmol})$ was stirred with $\mathrm{K}_{2} \mathrm{CO}_{3}(207 \mathrm{mg}, 1.5 \mathrm{mmol})$ and $\mathrm{I}_{2}(254 \mathrm{mg}, 1.0$ $\mathrm{mmol}$ ) in the presence of activated molecular sieves at room temperature under $\operatorname{argon}$ for $3 \mathrm{~h}$. Then the $\mathrm{HCl}$ salt of L-histidine methyl ester (484 mg, $2.0 \mathrm{mmol}$ ) and $\mathrm{K}_{2} \mathrm{CO}_{3}(414 \mathrm{mg}, 3.0 \mathrm{mmol}$ ) were added, and the mixture was stirred at $40^{\circ} \mathrm{C}$ under argon for $14 \mathrm{~h}$. The mixture was concentrated by rotary evaporation to give a crude product, which was subsequently treated with $\mathrm{Ac}_{2} \mathrm{O}$ in pyridine and purified by flash chromatography (silica gel; EtOAc/ $\left.\mathrm{MeOH} / \mathrm{Et}_{3} \mathrm{~N}, 98: 1: 1\right)$ to give compound 18Ac (302 mg, 54\% yield). $\mathrm{C}_{23} \mathrm{H}_{31} \mathrm{~N}_{3} \mathrm{O}_{13}$; yellow foam; $[\alpha]^{25}+31.83$ (c 3.9, $\mathrm{CH}_{2} \mathrm{Cl}_{2}$ ); IR $v_{\max }$ (neat) $3348,1745,1678 \mathrm{~cm}^{-1} ;{ }^{1} \mathrm{H}$ NMR $\left(\mathrm{CDCl}_{3}, 400 \mathrm{MHz}\right) \delta 8.24$ (1 H, br), $7.51(1 \mathrm{H}, \mathrm{s}), 6.77(1 \mathrm{H}, \mathrm{s}), 5.77(1 \mathrm{H}, \mathrm{dd}, J=6.2,3.8$ $\mathrm{Hz}), 5.49(1 \mathrm{H}, \mathrm{t}, J=5.6 \mathrm{~Hz}), 5.45(1 \mathrm{H}, \mathrm{d}, J=3.2 \mathrm{~Hz}), 5.03(1$ $\mathrm{H}, \mathrm{dd}, J=10.4,5.2 \mathrm{~Hz}), 4.74-4.70(1 \mathrm{H}, \mathrm{m}), 4.32(1 \mathrm{H}, \mathrm{dd}, J=$ 12.0, $4.8 \mathrm{~Hz}), 4.17(1 \mathrm{H}, \mathrm{dd}, J=12.0,5.6 \mathrm{~Hz}), 3.64(3 \mathrm{H}, \mathrm{s}), 3.12$ $(1 \mathrm{H}, \mathrm{dd}, J=14.9,5.2 \mathrm{~Hz}), 2.99(1 \mathrm{H}, \mathrm{dd}, J=14.9,4.6 \mathrm{~Hz}), 2.32$ (3 H, s), $2.11(3 \mathrm{H}, \mathrm{s}), 2.10(3 \mathrm{H}, \mathrm{s}), 2.05(3 \mathrm{H}, \mathrm{s}), 2.04(3 \mathrm{H}, \mathrm{s})$; ${ }^{13} \mathrm{C} \mathrm{NMR}\left(\mathrm{CDCl}_{3}, 100 \mathrm{MHz}\right) \delta 170.4,170.1,169.6,169.42,169.36$, 169.2, 166.2, 135.0, 134.5, 114.4, 72.0, 69.7, $68.6(2 \times), 61.0,52.2$, $52.0,28.4,20.60,20.55,20.51,20.49,20.3$; HRMS (ESI) calcd for $\mathrm{C}_{23} \mathrm{H}_{32} \mathrm{~N}_{3} \mathrm{O}_{13}$ 558.1930, found $m / z$ 558.1927 [M + H] $]^{+}$.

$N_{\alpha^{-}}$-Acetyl- $N_{\varepsilon^{-}}(\mathbf{2}, 3,4,5,6-O$-pentaacetylgluconyl)-L-lysine Methyl Ester (19Ac). According to the general procedure for oxidative amidation of aldose, a methanolic solution of D-glucose $(180 \mathrm{mg}$, $1.0 \mathrm{mmol}$ ) was stirred with $\mathrm{K}_{2} \mathrm{CO}_{3}(207 \mathrm{mg}, 1.5 \mathrm{mmol})$ and $\mathrm{I}_{2}(305$ $\mathrm{mg}, 1.2 \mathrm{mmol})$ in the presence of activated molecular sieves at room temperature under argon for $3 \mathrm{~h}$. Then the $\mathrm{HCl}$ salt of L-lysine methyl ester $(466 \mathrm{mg}, 2.0 \mathrm{mmol})$ and $\mathrm{K}_{2} \mathrm{CO}_{3}(414 \mathrm{mg}, 3.0 \mathrm{mmol})$ were added, and the mixture was stirred at $40{ }^{\circ} \mathrm{C}$ under argon for $14 \mathrm{~h}$. The mixture was concentrated by rotary evaporation to give a crude product, which was subsequently treated with $\mathrm{Ac}_{2} \mathrm{O}$ in pyridine and purified by flash chromatography (silica gel; EtOAc) to give compound 19Ac (460 mg, 78\% yield).

Alternatively, a methanolic solution of D-glucose $(180 \mathrm{mg}, 1.0$ mmol) was stirred with the $\mathrm{HCl}$ salt of L-lysine methyl ester (933 $\mathrm{mg}, 4.0 \mathrm{mmol})$ and $\mathrm{I}_{2}(508 \mathrm{mg}, 2.0 \mathrm{mmol})$ in the presence of $\mathrm{K}_{2} \mathrm{CO}_{3}$ $(1.11 \mathrm{~g}, 8.0 \mathrm{mmol})$ at room temperature for $14 \mathrm{~h}$ to give a crude product, which was subsequently treated with $\mathrm{Ac}_{2} \mathrm{O}$ in pyridine to give compound 19Ac (372 mg, 63\% yield). $\mathrm{C}_{25} \mathrm{H}_{38} \mathrm{~N}_{2} \mathrm{O}_{14}$; white foam; $[\alpha]^{25}+26.37\left(c 0.4, \mathrm{CH}_{2} \mathrm{Cl}_{2}\right.$ ); IR $v_{\max }$ (neat) 3316, 1751, $1663 \mathrm{~cm}^{-1} ;{ }^{1} \mathrm{H} \mathrm{NMR}\left(\mathrm{CDCl}_{3}, 400 \mathrm{MHz}\right) \delta 6.33-6.31(2 \mathrm{H}, \mathrm{br} \mathrm{s})$, $5.66(1 \mathrm{H}, \mathrm{t}, J=5.2 \mathrm{~Hz}), 5.43(1 \mathrm{H}, \mathrm{dd}, J=6.2,5.4 \mathrm{~Hz}), 5.24(1$ $\mathrm{H}, \mathrm{d}, J=5.2 \mathrm{~Hz}), 5.05-5.01(1 \mathrm{H}, \mathrm{m}), 4.57-4.52(1 \mathrm{H}, \mathrm{m}), 4.32$ $(1 \mathrm{H}, \mathrm{dd}, J=12.4,3.6 \mathrm{~Hz}), 4.11(1 \mathrm{H}, \mathrm{dd}, J=12.4,5.6 \mathrm{~Hz}), 3.73$ (3 H, s), $3.23(2 \mathrm{H}, \mathrm{dd}, J=12.8,6.4 \mathrm{~Hz}), 2.20(3 \mathrm{H}, \mathrm{s}), 2.10(3 \mathrm{H}$, s), $2.08(3 \mathrm{H}, \mathrm{s}), 2.05(3 \mathrm{H}, \mathrm{s}), 2.04(3 \mathrm{H}, \mathrm{s}), 2.03(3 \mathrm{H}, \mathrm{s})$, 1.84-1.77 (1 H, m), 1.72-1.65 (1 H, m), 1.54-1.47 (2 H, m), 1.37-1.26 (2 H, m); ${ }^{13} \mathrm{C} \mathrm{NMR}\left(\mathrm{CDCl}_{3}, 100 \mathrm{MHz}\right) \delta 172.6,170.5$, $170.0(2 \times), 169.6(2 \times), 169.2,166.0,71.6,69.4,69.0,68.8,61.6$, 52.4, 51.9, 38.8, 31.7, 28.8, 23.0, 22.2, $20.8(2 \times), 20.7(2 \times), 20.5$; HRMS (ESI) calcd for $\mathrm{C}_{25} \mathrm{H}_{39} \mathrm{~N}_{2} \mathrm{O}_{14} 591.2396$, found $\mathrm{m} / \mathrm{z} 591.2378$ $[\mathrm{M}+\mathrm{H}]^{+}$.

$\mathrm{N}$-(2,3,4,5,6-O-Pentaacetylgluconyl)-L-proline Methyl Ester (20Ac). According to the general procedure for oxidative amidation of aldose, a methanolic solution of D-glucose $(180 \mathrm{mg}, 1.0 \mathrm{mmol})$ was stirred with $\mathrm{K}_{2} \mathrm{CO}_{3}(207 \mathrm{mg}, 1.5 \mathrm{mmol})$ and $\mathrm{I}_{2}(254 \mathrm{mg}, 1.0$ $\mathrm{mmol}$ ) in the presence of activated molecular sieves at room temperature under argon for $3 \mathrm{~h}$. Then the $\mathrm{HCl}$ salt of L-proline methyl ester ( $325 \mathrm{mg}, 2.0 \mathrm{mmol}$ ) and $\mathrm{K}_{2} \mathrm{CO}_{3}(207 \mathrm{mg}, 1.5 \mathrm{mmol})$ were added, and the mixture was stirred at room temperature under $\operatorname{argon}$ for $48 \mathrm{~h}$. The mixture was concentrated by rotary evaporation to give a crude product, which was subsequently treated with $\mathrm{Ac}_{2} \mathrm{O}$ in pyridine and purified by flash chromatography (silica gel; EtOAc/ hexane, 2:1) to give compound 20Ac (207 $\mathrm{mg}, 40 \%$ yield). $\mathrm{C}_{22} \mathrm{H}_{31} \mathrm{NO}_{13}$; yellow foam; $[\alpha]^{25}+15.64\left(c 1.7, \mathrm{CH}_{2} \mathrm{Cl}_{2}\right)$; IR $v_{\max }$ (neat) $1748,1661 \mathrm{~cm}^{-1} ;{ }^{1} \mathrm{H} \mathrm{NMR}\left(\mathrm{CDCl}_{3}, 400 \mathrm{MHz}\right) \delta 5.75(1 \mathrm{H}$, dd, $J=7.0,3.4 \mathrm{~Hz}), 5.43(1 \mathrm{H}, \mathrm{d}, J=7.2 \mathrm{~Hz}), 5.39(1 \mathrm{H}, \mathrm{dd}, J$ $=8.0,3.2 \mathrm{~Hz}), 5.06-5.02(1 \mathrm{H}, \mathrm{m}), 4.44(1 \mathrm{H}, \mathrm{dd}, J=8.6,3.8$ $\mathrm{Hz}), 4.24(1 \mathrm{H}, \mathrm{dd}, J=12.5,3.0 \mathrm{~Hz}), 4.12(1 \mathrm{H}, \mathrm{dd}, J=12.5,5.2$ $\mathrm{Hz}), 3.81-3.76(1 \mathrm{H}, \mathrm{m}), 3.71(3 \mathrm{H}, \mathrm{s}), 3.47-3.41(1 \mathrm{H}, \mathrm{m})$, 2.20-2.15 (2 H, m), 2.14 (3 H, s), $2.13(3 \mathrm{H}, \mathrm{s}), 2.07$ (3 H, s), $2.06(3 \mathrm{H}, \mathrm{s}), 2.05(3 \mathrm{H}, \mathrm{s}), 2.04-1.97(2 \mathrm{H}, \mathrm{m}) ;{ }^{13} \mathrm{C} \mathrm{NMR}\left(\mathrm{CDCl}_{3}\right.$, $100 \mathrm{MHz}) \delta 171.5,170.1,169.4,169.3,169.08,169.05,164.0$, 69.4, 68.5, 68.4, 68.1, 61.3, 59.1, 52.0, 46.7, 28.6, 24.7, $20.63(2 \times)$, 20.55, 20.32, 20.26; HRMS (ESI) calcd for $\mathrm{C}_{22} \mathrm{H}_{31} \mathrm{NO}_{13} \mathrm{Na} 540.1688$, found $\mathrm{m} / \mathrm{z}, 540.1690[\mathrm{M}+\mathrm{Na}]^{+}$.

$\mathrm{N}$-(2,3,4,5,6-O-Pentaacetyl-D-gluconyl)glycyl-L-valine Methyl Ester (21Ac). According to the general procedure for oxidative amidation of aldose, a methanolic solution of D-glucose $(180 \mathrm{mg}$, $1.0 \mathrm{mmol})$ was stirred with $\mathrm{K}_{2} \mathrm{CO}_{3}(207 \mathrm{mg}, 1.5 \mathrm{mmol})$ and $\mathrm{I}_{2}(305$ $\mathrm{mg}, 1.2 \mathrm{mmol})$ in the presence of activated molecular sieves at room temperature under argon for $3 \mathrm{~h}$. Then the $\mathrm{HCl}$ salt of glycylL-valine methyl ester (449 mg, $2.0 \mathrm{mmol}$ ) and $\mathrm{K}_{2} \mathrm{CO}_{3}(207 \mathrm{mg}$, $1.5 \mathrm{mmol}$ ) were added, and the mixture was stirred at $40{ }^{\circ} \mathrm{C}$ under argon for $16 \mathrm{~h}$. The mixture was concentrated by rotary evaporation to give a crude product, which was subsequently treated with $\mathrm{Ac}_{2} \mathrm{O}$ in pyridine and purified by flash chromatography (silica gel; EtOAc/ hexane, 2:1) to give compound 21Ac (461 mg, 80\% yield). $\mathrm{C}_{24} \mathrm{H}_{36} \mathrm{~N}_{2} \mathrm{O}_{14}$; yellow foam; $[\alpha]^{25}{ }_{\mathrm{D}}+25.55\left(c 3.7, \mathrm{CH}_{2} \mathrm{Cl}_{2}\right)$; IR $v_{\max }$ (neat) $3366,1748,1677 \mathrm{~cm}^{-1} ;{ }^{1} \mathrm{H} \mathrm{NMR}\left(\mathrm{CDCl}_{3}, 400 \mathrm{MHz}\right) \delta 6.93$ $(1 \mathrm{H}$, br s), $6.62(1 \mathrm{H}$, br s), $5.66(1 \mathrm{H}, \mathrm{t}, J=4.8 \mathrm{~Hz}), 5.45(1 \mathrm{H}$, $\mathrm{dd}, J=6.6,4.6 \mathrm{~Hz}), 5.30(1 \mathrm{H}, \mathrm{d}, J=4.8 \mathrm{~Hz}), 5.08-5.04(1 \mathrm{H}$, $\mathrm{m}), 4.50(1 \mathrm{H}, \mathrm{dd}, J=8.8,5.2 \mathrm{~Hz}), 4.30(1 \mathrm{H}, \mathrm{dd}, J=12.4,3.8$ $\mathrm{Hz}), 4.13(1 \mathrm{H}, \mathrm{dd}, J=12.4,5.4 \mathrm{~Hz}), 4.01(1 \mathrm{H}, \mathrm{dd}, J=16.8,5.6$ $\mathrm{Hz}), 3.94(1 \mathrm{H}, \mathrm{dd}, J=16.8,5.2 \mathrm{~Hz}), 3.74(3 \mathrm{H}, \mathrm{s}), 2.21(3 \mathrm{H}, \mathrm{s})$, 2.19-2.12 (1 H, m), $2.11(3 \mathrm{H}, \mathrm{s}), 2.08$ (3 H, s), 2.07 (3 H, s), $2.05(3 \mathrm{H}, \mathrm{s}), 0.94(3 \mathrm{H}, \mathrm{d}, J=6.4 \mathrm{~Hz}), 0.91(3 \mathrm{H}, \mathrm{d}, J=6.8 \mathrm{~Hz})$; ${ }^{13} \mathrm{C} \mathrm{NMR}\left(\mathrm{CDCl}_{3}, 100 \mathrm{MHz}\right) \delta 171.6,169.9,169.3,169.2(2 \times)$, 168.7, 168.0, 166.3, 71.6, 69.1, 68.5, 68.3, 61.1, 57.2, 51.8, 42.3, 30.6, 20.4, $20.3(3 \times), 20.1,18.7,17.6$; HRMS (ESI) calcd for $\mathrm{C}_{24} \mathrm{H}_{36} \mathrm{~N}_{2} \mathrm{O}_{14} \mathrm{Na} 599.2059$, found $m / z$ 599.2052 [M $\left.+\mathrm{Na}\right]^{+}$.

$\mathrm{N}$-Maltonyl-L-lysyl-D-alanyl-D-alanine Trifluoroacetic Salt (30). According to the general procedure for oxidative amidation of aldose, a methanolic solution of D-maltose monohydrate (72 mg, $0.2 \mathrm{mmol})$ was stirred with $\mathrm{K}_{2} \mathrm{CO}_{3}(42 \mathrm{mg}, 0.3 \mathrm{mmol})$ and $\mathrm{I}_{2}(62$ $\mathrm{mg}, 0.2 \mathrm{mmol}$ ) at room temperature under argon for $3 \mathrm{~h}$. Then the TFA salt of L-lysyl-D-alanyl-D-alanine $(50 \mathrm{mg}, 0.1 \mathrm{mmol})$ and 
$\mathrm{K}_{2} \mathrm{CO}_{3}(62 \mathrm{mg}, 0.2 \mathrm{mmol})$ were added, and the mixture was stirred at $40{ }^{\circ} \mathrm{C}$ under argon for $16 \mathrm{~h}$. The mixture was filtrated, and subsequently purified by gel filtration (Sephadex G-10; 10\% aqueous $\mathrm{AcOH})$. The filtrate was concentrated under reduced pressure, and the residue was treated with trifluoroacetic acid. After the excess trifluoroacetic acid was removed under reduced pressure, the desired product $30(49 \mathrm{mg}, 0.66 \mathrm{mmol})$ was obtained in $66 \%$ yield. $\mathrm{C}_{24} \mathrm{H}_{44} \mathrm{~N}_{4} \mathrm{O}_{15} \cdot \mathrm{CF}_{3} \mathrm{CO}_{2} \mathrm{H}$; white solid (hygroscopic); $[\alpha]^{25}$ $+23.83\left(c\right.$ 1.5, $\left.\mathrm{H}_{2} \mathrm{O}\right)$; IR $v_{\max }(\mathrm{KBr}) 3429,1681 \mathrm{~cm}^{-1}$; ${ }^{1} \mathrm{H}$ NMR $\left(\mathrm{D}_{2} \mathrm{O}, 400 \mathrm{MHz}\right) \delta 5.16(1 \mathrm{H}, \mathrm{d}, J=3.6 \mathrm{~Hz}), 4.35(1 \mathrm{H}, \mathrm{d}, J=7.2$ $\mathrm{Hz}), 4.32(1 \mathrm{H}, \mathrm{d}, J=2.4 \mathrm{~Hz}), 4.20(1 \mathrm{H}, \mathrm{dd}, J=6.4,2.4 \mathrm{~Hz})$, 4.16-4.09 (2 H, m), 3.99-3.65 (9 H, m), $3.59(1 \mathrm{H}, \mathrm{dd}, J=9.8$, $3.8 \mathrm{~Hz}), 3.45(1 \mathrm{H}, \mathrm{t}, J=9.4 \mathrm{~Hz}), 3.30-3.25(2 \mathrm{H}, \mathrm{m}), 1.86-1.80$ $(2 \mathrm{H}, \mathrm{m}), 1.62-1.52(2 \mathrm{H}, \mathrm{m}), 1.41(3 \mathrm{H}, \mathrm{d}, J=7.6 \mathrm{~Hz}), 1.39-1.37$ $(2 \mathrm{H}, \mathrm{m}), 1.34(3 \mathrm{H}, \mathrm{d}, J=7.2 \mathrm{~Hz}) ;{ }^{13} \mathrm{C}$ NMR $\left(\mathrm{D}_{2} \mathrm{O}, 100 \mathrm{MHz}\right) \delta$ 177.1, 174.4, 174.1, 169.8, 163.2, 162.9, 118.0, 115.1, 100.7, 82.2, $73.2,72.7,72.5,72.1,72.0,71.9,69.6,62.4,60.6,53.4,50.0,49.5$, 38.9, 30.8, 28.4, 21.8, 17.1, 16.6; HRMS (ESI) calcd for $\mathrm{C}_{24} \mathrm{H}_{45} \mathrm{~N}_{4} \mathrm{O}_{15}$ 629.2881, found $\mathrm{m} / z$ 629.2878 [M - $\left.\mathrm{CF}_{3} \mathrm{CO}_{2}\right]^{+}$.

Conjugation of D-Lactose with Polylysine. According to the general procedure for oxidative amidation of aldose, a methanolic solution of D-lactose monohydrate $(180 \mathrm{mg}, 0.5 \mathrm{mmol})$ was stirred with $\mathrm{K}_{2} \mathrm{CO}_{3}(97 \mathrm{mg}, 0.7 \mathrm{mmol})$ and $\mathrm{I}_{2}(153 \mathrm{mg}, 0.6 \mathrm{mmol})$ at room temperature under argon for $3 \mathrm{~h}$. Then the $\mathrm{HBr}$ salt of poly-L-lysine $\left(20.9 \mathrm{kDa}, M_{\mathrm{w}} / M_{\mathrm{n}}=1.24,10 \mathrm{mg}, 0.5 \mu \mathrm{mol}\right.$, containing approximately 93 lysyl residues per poly-L-lysine molecule) and $\mathrm{K}_{2} \mathrm{CO}_{3}(10 \mathrm{mg}, 0.07 \mathrm{mmol})$ were added, and the mixture was stirred at $40{ }^{\circ} \mathrm{C}$ under argon for $24 \mathrm{~h}$. The mixture was concentrated under reduced pressure. The residue was dissolved in water $(10 \mathrm{~mL})$ and subjected to dialysis with cellulose ester membrane ( $5 \mathrm{kDa}$ MWCO) by deionized water $(2 \mathrm{~L})$. The dialysis was repeated 2 times with $2 \mathrm{~L}$ of fresh deionized water for 6 and $14 \mathrm{~h}$, respectively, to give the lactonyl-polylysine conjugate as shown by a sulfuric acid-phenol assay.

Conjugation of D-Lactose with Bovine Serum Albumin. According to the general procedure for oxidative amidation of aldose, a methanolic solution of D-lactose monohydrate $(180 \mathrm{mg}$, $0.5 \mathrm{mmol})$ was stirred with $\mathrm{K}_{2} \mathrm{CO}_{3}(9.3 \mathrm{mg}, 67 \mu \mathrm{mol})$ and $\mathrm{I}_{2}(13.6$ $\mathrm{mg}, 54 \mu \mathrm{mol}$ ) at room temperature under argon for $3 \mathrm{~h}$. Then bovine serum albumin $(50 \mathrm{mg}, 0.8 \mu \mathrm{mol}, 66 \mathrm{kDa}$, containing 59 lysyl residues per BSA molecule) and $\mathrm{K}_{2} \mathrm{CO}_{3}(9.3 \mathrm{mg}, 67 \mu \mathrm{mol})$ were added, and the mixture was stirred at room temperature for $24 \mathrm{~h}$. The mixture was filtered, and thoroughly rinsed with deionized water $(50 \mathrm{~mL})$ to give the lactonyl-BSA conjugate. The MALDITOF MS analysis of the glycoprotein indicated that approximately 4 lactosyl moieties were linked to BSA (see the Supporting Information, Figure S1).

$\mathrm{N}$-Ethyl 2,3,4,5-O-Tetraacetyl-L-xylonamide (32Ac). According to the general procedure for decarboxylative amidation of $\alpha$-keto acid, an aqueous solution of 2-keto-L-gulonic acid (194 mg, 1.0 mmol) was stirred with $\mathrm{EtNH}_{2}$ ( $1 \mathrm{~mL}$ of $70 \%$ aqueous solution) and $\mathrm{I}_{2}(508 \mathrm{mg}, 2.0 \mathrm{mmol})$ at room temperature for $8 \mathrm{~h}$ to give a crude product, which was subsequently treated with $\mathrm{Ac}_{2} \mathrm{O}$ in pyridine to give amide 32Ac (264 mg, $73 \%$ yield). Compound 32Ac (enantiomer of 3aAc): $[\alpha]^{25}-11.6\left(c 0.65, \mathrm{CH}_{2} \mathrm{Cl}_{2}\right) ;{ }^{1} \mathrm{H}$ NMR $\left(\mathrm{CDCl}_{3}, 400 \mathrm{MHz}\right) \delta 6.01(1 \mathrm{H}$, br s $), 5.61(1 \mathrm{H}, \mathrm{dd}, J=5.6,4.8$ $\mathrm{Hz}), 5.33(1 \mathrm{H}, \mathrm{d}, J=4.8 \mathrm{~Hz}), 5.30(1 \mathrm{H}, \mathrm{dd}, J=10.4,6.0 \mathrm{~Hz})$, $4.32(1 \mathrm{H}, \mathrm{dd}, J=12.0,4.8 \mathrm{~Hz}), 4.04(1 \mathrm{H}, \mathrm{dd}, J=12.0,6.0 \mathrm{~Hz})$,
3.36-3.25 (2 H, m), $2.21(3 \mathrm{H}, \mathrm{s}), 2.09(3 \mathrm{H}, \mathrm{s}), 2.08(3 \mathrm{H}, \mathrm{s})$, $2.06(3 \mathrm{H}, \mathrm{s}), 1.14(3 \mathrm{H}, \mathrm{t}, J=7.2 \mathrm{~Hz}) ;{ }^{13} \mathrm{C} \mathrm{NMR}\left(\mathrm{CDCl}_{3}, 100\right.$ MHz) $\delta 170.2,169.6,169.1,168.9,165.5,71.7,69.6,69.2,61.7$, 34.4, 20.8, $20.7(2 \times), 20.5,14.7$; HRMS calcd for $\mathrm{C}_{15} \mathrm{H}_{23} \mathrm{NO}_{9} \mathrm{Na}$ 384.1265 , found $m / z 384.1269[\mathrm{M}+\mathrm{Na}]^{+}$.

$N$-Hexyl $(3 S, 4 R, 5 R, 6 S, 7 R)$-4-Acetamido-3,5,6,7,8-pentaacetoxyoctanamide (33Ac). According to the general procedure for decarboxylative amidation of $\alpha$-keto acid, an aqueous solution of sialic acid (309 mg, $1.0 \mathrm{mmol}$ ) was stirred with hexylamine $(404 \mathrm{mg}$, $4.0 \mathrm{mmol}$ ) and $\mathrm{I}_{2}(508 \mathrm{mg}, 2.0 \mathrm{mmol})$ at room temperature for $10 \mathrm{~h}$ to give a glyconamide product. ${ }^{1} \mathrm{H}$ NMR $\left(\mathrm{D}_{2} \mathrm{O}, 400 \mathrm{MHz}\right) \delta 4.48$ $(1 \mathrm{H}, \mathrm{t}, J=6.8 \mathrm{~Hz}), 3.90(2 \mathrm{H}, \mathrm{br} \mathrm{s}), 3.80(1 \mathrm{H}, \mathrm{dd}, J=11.6,3.6$ $\mathrm{Hz}), 3.75-3.70(1 \mathrm{H}, \mathrm{m}), 3.60(1 \mathrm{H}, \mathrm{dd}, J=11.6,6.0 \mathrm{~Hz}), 3.45(1$ $\mathrm{H}, \mathrm{d}, J=8.0 \mathrm{~Hz}), 3.16\left(2 \mathrm{H}, \mathrm{t}, J=6.8 \mathrm{~Hz}, \mathrm{H}-1^{\prime}\right), 2.38-2.36(2$ $\mathrm{H}, \mathrm{m}, \mathrm{H}-2), 2.06(3 \mathrm{H}, \mathrm{s}), 1.48(2 \mathrm{H}, \mathrm{t}, J=6.8 \mathrm{~Hz}), 1.32(6 \mathrm{H}, \mathrm{br}$ $\mathrm{m}), 0.86(3 \mathrm{H}, \mathrm{t}, J=6.8 \mathrm{~Hz})$.

The crude product was treated with $\mathrm{Ac}_{2} \mathrm{O}$ in pyridine to give compound 33Ac (350 mg, $61 \%$ overall yield). $\mathrm{C}_{26} \mathrm{H}_{42} \mathrm{~N}_{2} \mathrm{O}_{12}$; yellow foam, $[\alpha]^{25}-4.71$ ( c 1.10, $\mathrm{CH}_{2} \mathrm{Cl}_{2}$ ); IR $v_{\max }$ (neat) 3289, 1750, $1652 \mathrm{~cm}^{-1} ;{ }^{1} \mathrm{H}$ NMR $\left(\mathrm{CDCl}_{3}, 400 \mathrm{MHz}\right) \delta 6.50(1 \mathrm{H}$, br s$), 5.86$ $(1 \mathrm{H}, \mathrm{d}, J=10.4 \mathrm{~Hz}), 5.39(1 \mathrm{H}, \mathrm{dd}, J=8.4,2.0 \mathrm{~Hz}), 5.27(1 \mathrm{H}$, $\mathrm{dd}, J=10.0,2.0 \mathrm{~Hz}), 5.08(1 \mathrm{H}, \mathrm{dd}, J=8.8,4.8 \mathrm{~Hz}), 5.05-5.00$ $(1 \mathrm{H}, \mathrm{m}), 4.37(1 \mathrm{H}, \mathrm{t}, J=10.4 \mathrm{~Hz}), 4.24(1 \mathrm{H}, \mathrm{dd}, J=12.4,3.2$ $\mathrm{Hz}), 3.99(1 \mathrm{H}, \mathrm{dd}, J=12.8,5.6 \mathrm{~Hz}), 3.24-3.16(2 \mathrm{H}, \mathrm{m}), 2.38$ (1 $\mathrm{H}, \mathrm{dd}, J=13.2,4.8 \mathrm{~Hz}), 2.29(1 \mathrm{H}, \mathrm{dd}, J=13.2,8.8 \mathrm{~Hz}), 2.09(3$ $\mathrm{H}, \mathrm{s}), 2.05$ (6 H, s), $2.04(9 \mathrm{H}, \mathrm{s}), 1.53-1.46(2 \mathrm{H}, \mathrm{m}), 1.34-1.25$ $(6 \mathrm{H}, \mathrm{m}), 0.87(3 \mathrm{H}, \mathrm{t}, J=6.8 \mathrm{~Hz}) ;{ }^{13} \mathrm{C} \mathrm{NMR}\left(\mathrm{CDCl}_{3}, 100 \mathrm{MHz}\right)$ $\delta$ 171.2, 170.3, 169.8, 169.6, 169.5, 169.2, 167.9, $68.7(2 \times), 67.9$, 67.7, 61.9, 49.5, 39.8, 38.9, 31.5, 29.3, 26.6, 23.2, 22.6, 21.0, 20.9, 20.8, 20.7 (2×), 14.1; HRMS calcd for $\mathrm{C}_{26} \mathrm{H}_{43} \mathrm{~N}_{2} \mathrm{O}_{12}$ 575.2811, found $m / z, 575.2804[\mathrm{M}+\mathrm{H}]^{+}$.

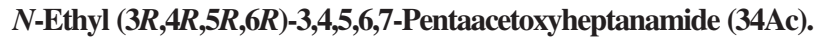
According to the general procedure for decarboxylative amidation of $\alpha$-keto acid, an aqueous solution of KDO (100 mg, $0.39 \mathrm{mmol})$ was stirred with ethylamine $(70 \% \mathrm{wt}, 1.0 \mathrm{~mL})$ and $\mathrm{I}_{2}(125 \mathrm{mg}$, $0.49 \mathrm{mmol}$ ) at room temperature for $12 \mathrm{~h}$ to give a crude product, which was subsequently treated with $\mathrm{Ac}_{2} \mathrm{O}$ in pyridine to give amide 34Ac (130 mg, 74\% yield). $\mathrm{C}_{19} \mathrm{H}_{29} \mathrm{NO}_{11}$; white solid, mp 149.1-151.3 ${ }^{\circ} \mathrm{C} ;[\alpha]^{25}+36.11\left(c 0.7, \mathrm{CH}_{2} \mathrm{Cl}_{2}\right)$; IR $v_{\max }$ (neat) $2924,1743,1649$ $\mathrm{cm}^{-1} ;{ }^{1} \mathrm{H} \mathrm{NMR}\left(\mathrm{CDCl}_{3}, 400 \mathrm{MHz}\right) \delta 5.80(1 \mathrm{H}, \mathrm{br} \mathrm{s}), 5.43(1 \mathrm{H}$, $\mathrm{dd}, J=8.8,2.8 \mathrm{~Hz}), 5.36(1 \mathrm{H}, \mathrm{dd}, J=7.6,3.2 \mathrm{~Hz}), 5.30-5.24(1$ $\mathrm{H}, \mathrm{m}), 5.11-5.07(1 \mathrm{H}, \mathrm{m}), 4.22(1 \mathrm{H}, \mathrm{dd}, J=12.4,2.8 \mathrm{~Hz}), 4.10$ $(1 \mathrm{H}, \mathrm{dd}, J=12.4,5.2 \mathrm{~Hz}), 3.33-3.21(2 \mathrm{H}, \mathrm{m}), 2.51(1 \mathrm{H}, \mathrm{dd}, J$ $=14.8,4.8 \mathrm{~Hz}), 2.39(1 \mathrm{H}, \mathrm{dd}, J=14.8,7.2 \mathrm{~Hz}), 2.11(3 \mathrm{H}, \mathrm{s})$, $2.10(3 \mathrm{H}, \mathrm{s}), 2.07(3 \mathrm{H}, \mathrm{s}), 2.06(3 \mathrm{H}, \mathrm{s}), 2.05(3 \mathrm{H}, \mathrm{s}), 1.13(3 \mathrm{H}$, $\mathrm{t}, J=7.2 \mathrm{~Hz}) ;{ }^{13} \mathrm{C} \mathrm{NMR}\left(\mathrm{CDCl}_{3}, 100 \mathrm{MHz}\right) \delta 170.3,170.2,169.7$ (2×) $169.5,167.7,70.2,68.1,67.8,67.5,61.8,38.1,34.6,21.0$, 20.9, $20.8(2 \times), 20.7,14.8$; HRMS calcd for $\mathrm{C}_{19} \mathrm{H}_{29} \mathrm{NO}_{11} \mathrm{Na}$ 470.1633, found $\mathrm{m} / \mathrm{z} 470.1628[\mathrm{M}+\mathrm{Na}]^{+}$.

Acknowledgment. We thank the National Science Council for financial support.

Supporting Information Available: Experimental procedures, product characterization, and NMR spectra. This material is available free of charge via the Internet at http://pubs.acs.org.

JO802338K 